Portland State University

PDXScholar

1978

\title{
Description and Analysis of the Public Guardian and Conservator Program in Multnomah County, Oregon
}

Dianne Wyers

Portland State University

Follow this and additional works at: https://pdxscholar.library.pdx.edu/open_access_etds

Part of the Social Work Commons

Let us know how access to this document benefits you.

\section{Recommended Citation}

Wyers, Dianne, "Description and Analysis of the Public Guardian and Conservator Program in Multnomah County, Oregon" (1978). Dissertations and Theses. Paper 3409.

https://doi.org/10.15760/etd.5293

This Thesis is brought to you for free and open access. It has been accepted for inclusion in Dissertations and Theses by an authorized administrator of PDXScholar. Please contact us if we can make this document more accessible: pdxscholar@pdx.edu. 
DESCRIPTION AND ANALYSIS OF THE PUBLIC GUARDIAN AND CONSERVATOR PROGRAM IN MULTNOMAH COUNTY, OREGON

Dianne Wyers

A practicum submitted in partial fulfillment of the requirements for the degree of

MASTER OF SOCIAL WORK

Portland State University

1978 
APPROVED :

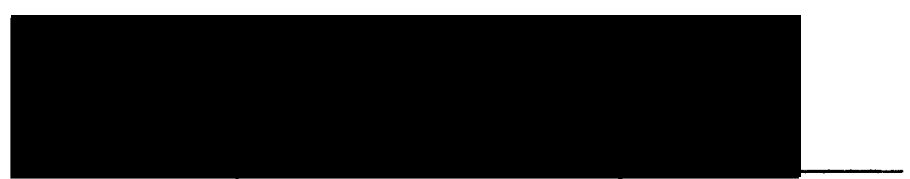

Gerald FAey, Ph.D., Advi|jor 


\section{ACKNOWLEDGMENTS}

I would like to thank my advisor Jerry Frey for his guidance throughout this project. I would also like to thank Lydia Strnad of Metropolitan Family Service, as well as Paul Nizdil, Multnomah County Public Guardian and Conservator. All three gave time, special insight and encouragement to this project. 
TABLE OF CONTENTS

PAGE

ACKNOWLEDGMENTS

LIST OF TABLES vii

LIST OF FIGURES ix CHAPTER

I INTRODUCTION . . . . . . . . . . . . . . 1

II ISSUES : LEGAL, POLITICAL \& SOCIAL . . . . 3

Self Determination vs. State's Rights . . . . . . . . . . 3

Basis of Appointment . . . . . . . 4

The Aged in Need . . . . . . . . . . 5

The Role of the Physician . . . . . 6

Decisions to Spend . . . . . . . . . 8

Restoration to Competency . . . . . 10

The Least Restrictive Alternative . . 11

III HISTORICAL DEVELOPMENT . . . . . . . 13

England . . . . . . . . . . . . . 13

Early America . . . . . . . . . 16

The 1960s . . . . . . . . . . . . 19

The $1970 \mathrm{~s}$. . . . . . . . . . . . . 20 
IV DEVELOPMENT OF THE PUBLIC GUARDIAN AND CONSERVATOR PROGRAM IN MULTNOMAH

COUNTY, OREGON . . . . . . . . . . . . . . 23

Early Development . . . . . . . . . 24

Legislation . . . . . . . . . . 27

Implementation . . . . . . . . . . . 29

Trial Period. . . . . . . . . . 30

Program Establishment. . . . . . . 32

1973 Legislative Changes . . . . . . 32

Veteran's Program . . . . . . . 33

Coordination with Community . . . . 34

$\mathrm{V}$ THE CURRENT PROGRAM OF PUBLIC GUARDIAN-

SHIP AND CONSERVATORSHIP IN MULTNOMAH

COUNTY, OREGON . . . . . . . . . . . . 36

Legal Base and General Policy

Statement of Program . . . . . 37

Legal Definitions and Process in

Establishment of Guardianships and Conservatorships . . . . . . 38

Staff . . . . . . . . . . . 41

Public Guardianship . . . . . . . 43

Public Conservatorship . . . . . . 45

Physical Plant. . . . . . . . . 47

Budget . . . . . . . . . . . 48

Characteristics of Current

Population Served . . . . . . . . 49

Selected Characteristics of all

Closed Cases . . . . . . . . 59

Conclusions about Entire Population

Served by the Program .. . . . 62 
CHAPTER

PAGE

VI ANCILLARY SERVICES . . . . . . . . . . . 64

Area Agency on Aging . . . . . . . . . 64

Area Hospitals . . . . . . . . . 65

Adult and Family Services Division. . 66

Metropolitan Family Service. . . . . 67

The Role of Protective Service. . . . 68

Collaboration Between Public Guardian/ Conservator and Protective

Services . . . . . . . . . . 71

VII CONCLUSIONS . . . . . . . . . . . . . . 76

Strengths of the Program . . . . . . . 77

Limitations of the Program . . . . . 78

Planning for the Future . . . . . 80

Multnomah County Program . . . . 80

State-Wide Program. . . . . . . 82

FOOTNOTE REFERENCES . . . . . . . . . . . . . . 89

BIBLIOGRAPHY . . . . . . . . . . . . . . . 92

APPENDIX A . . . . . . . . . . . . . . . . . 94

APPENDIX B ................... 106 


\section{LIST OF TABLES}

TABLE

PAGE

I Marital Status of Male and Female Protected

Persons, by Number and Percent. . . . . 49

II Age Range and Sex of Protected Persons,

by Number and Percent . . . . . . . . 50

III Age Classification of Total Cases Under and

Over Age 60 and Sex, by Number

and Percent . . . . . . . . . . . 51

IV Year and Type of Appointment, by Number . . . . 52

$\mathrm{V}$ Level of Total Assets of Active

Conservatorships, by Number and

Percent . . . . . . . . . . 52

VI Total Source of Income of Active Conserva-

torships, by Number and Percent . . . . 53

VII Living Arrangement of Protected Persons at

Time of Appointment and at Time of

First Annual Accounting to the Court,

One Year Later, by Number and Percent. . . 54

VII Medical/Social Conditions Necessitating Legal

Intervention at Time of Client Referral,

by Number and Percent . . . . . . . . 56 
IX Degree of Mobility of Total Protected Persons, by Number and Percent . . . . . . . . 57

$X$ Initial Referral and Primary Service-

Providing Agencies, by Number. . . . . . 66

XI Age Range and Sex of Closed Cases, by

Number and Percent . . . . . . . . . 107

XII Year and Type of Appointment of Closed

Cases, by Number . . . . . . . . . . 107

XIII Initial Referral and Primary Service-

Providing Agencies of Closed Cases,

by Number . . . . . . . . . . . . 108

XIV Reasons for Termination of Closed Cases,

by Number and Percent . . . . . . . . 108 


\section{LIST OF FIGURES}

FIGURE

PAGE

1. Public Guardian Conservator Program

Process . . . . . . . . . . . 40 
CHAPTER I

\section{INTRODUCTION}

The ultimate measurement of the quality of our civilization is the way in which the rights and dignity of the impaired individual are protected. . . . No single group of individuals, no segment of our population, more poignantly challenges our moral convictions and social values about the worth of human life and dignity and rights of the individual than do those (older) people whose mental and physical impairments place them at the mercy of society. . . 1

The law and the public programs designed to implement the intent of the law should serve as a model for the way in which needs are met in our society. With this view in mind, a study of the Public Guardian and Conservator program has been undertaken.

This study is the first written description of a young program designed to offer unique services to legally incapacitated persons. Public guardianship and conservatorship evolved from an early notion that a guarantee of rights is a public as well as a private responsibility. The question of the extent of public responsibility required as well as implementation will be examined.

There is no apparent criteria to guide planning. Similar programs in other states have unique developmental 
histories and are designed and implemented in a variety of ways. This results from an incredible variation in the language of the law as well as its interpretation. Because Oregon's program is new and serves only Multnomah County residents, future planning for expansion will be discussed. This study will review selected issues viewed as important considerations in the development and implementation of guardianship and conservatorship services. An historical overview will provide a sense of the significance of legal intervention over time and the influences that have shaped our thinking.

Oregon's experience in planning and developing legislation for a public program will be documented. The state's only existing program in Multnomah County will be reviewed including a discussion of the population served.

The conclusions will focus on planning for the future. Included will be suggestions for expansion, with a discussion of elements necessary to a successful program. Such expansion may serve to help fulfill the fundamental belief that dignity comes with choice. 
ISSUES: LEGAL, POLITICAL AND SOCIAL

Because guardianship ${ }^{2}$ is essentially a matter of public trust, it is important to understand some of the significant issues involved in the process. The issues are as relevant to public as well as to private guardianship/conservatorship functions.

SELF DETERMINATION VS. STATE'S RIGHTS

The Iowa Law Review, which devotes an entire volume to guardianship, states,

In few other areas is a proper handling of a creation of law so important to so many persons and so many human relationships. While the law is a major force in advancing the welfare of the disadvantaged and the disabled affected by guardianship proceedings, all who adninister the intent of the law must be cognizant of the issues. 3

The overriding concern is the need to balance a person's right to protection with his right to self determination.

Some older people may have always been only marginally competent. For many, inability to continue the management of their own finances results from the changes in themselves, their environment or a combination of both. Despite a deep desire to help older men and women with their affairs, the difficulties encountered in doing so can be overwhelming. Part of the problem lies in the fact that judges, lawyers, legislators, doctors, psychiatrists, social workers, relatives, friends are caught in the conflict between a conviction 
that all adults are entitled to make their own decisions even if unwise and an equally strong belief that those who need protection ought to have it. 4

\section{BASIS OF APPOINTMENT}

A major consideration must be the necessity to be as precise as possible in the appointment of a guardian or conservator, as "this kind of intervention is a basic deprivation of a right cherished in a free society: the right of an individual to self determination." 5 Such legal intervention in the name of help and protection suspends almost entirely an adult's power to create legal relations with others. Essentially, a protected person may not direct the dispersal or use of property, enter valid contracts, marry, change residence or choose agents such as doctors and lawyers. Probably he will be unable to write a valid will and possibly be denied the right to vote.

While non-adversary proceedings are used, which in theory, only the individual's best interests are at stake, there may be interests present that are quite opposite to that of the protected person. These interests may be represented by relatives, creditors and potential heirs.

It is rather curious that in a legal system which ordinarily is very cognizant of checks and balances, persons are allowed the weapon of incompetency in promoting self interest... the obligation in maximizing benefit to the ward and not the ward's heirs, is basic.

As long as the appointment of a "surrogate" is to be made, determination of that person to be free to make decisions 
based on the protected person's best interests has to be essential to the process.

\section{THE AGED IN NEED}

The aged are a particularly vulnerable group for guardianship or conservatorship. The Yale Law Review discusses the concerns of this population as they, more often than other groups, are affected by guardianship law. It has been suggested that it is often too easy to produce evidence of some form of incapacity in the aged, to satisfy minimal requirements of the court. Any shift from the currently dominant concern with mental illness toward more specific findings about the person's actual conduct and capacities should be seen as progress. Competent medical, psychiatric and social work testimony can be essential and should be available to the court prior to ruling on the need for legal intervention.

The young and the middle-aged are usually seen as having more realistic hope of recovery from psychological disturbances and/or physical disabilities and the courts seem more reluctant to impose restrictions. In addition, fewer relatives are said to push in expectation of personal benefit with those persons other than the aged.

Alexander and Lewin indicate that functional competence is a central test for the aged. The most common functional defect is said to be memory loss. The Yale Law 


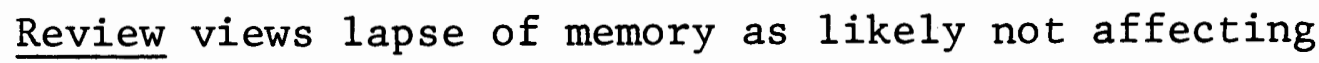
property management abilities but as a usual and mild form of old age. The Review suggests courts may act on such evidence with the fear that this deterioration will soon be displaced by acute problems making the individual incapable of self-care and decision making. What we so often fail to recognize is reflected in a statement made by Herbert $\mathrm{J}$. Weiss, M.D., Chief of Psychiatry in Mt. Sinai Hospital in Cleveland, Ohio in an address titled, "The Harm of Neglect."

As I said, I felt very clearly that a significant proportion of impaired older people are eminently treatable. The conditions are reversable, and one has to get rid of that tag of chronic brain syndrome which is a way of not thinking about something. The patient should be viewed from an assessment that puts the emphasis on functional capacity: the capacity for adaptation. This is an entirely different frame of reference. 8

The burden of proof in non-adversary proceedings such as guardianship may not include such an assessment. In fact, at times, medical evidence may not be required.

\section{THE ROLE OF THE PHYSICIAN}

The role of the physician has much to contribute to the evaluation of both status and therapy of the incapacitated (aged) individual. Irreversible (mental) incapacity as well as treatable chronic or acute disease can be determined. The physician with a broad view of the situation may be able to do much toward the restoration of 
adequate functioning and prevention of unnecessary institutionalization. The role of the physician is essential.

Alexander and Lewin found that a review of the literature on medical criteria for incompetency reveals a distorted picture. Generally, the existence and extent of "incompetence" can best be determined by direct evidence of words, acts, appearance and physical condition for lay and medical opinion either based on close association with or observation of the alleged incompetent. They go on to say the problem in defining what represents good or poor management is easy at the extremes.

In the middle ground, no amount of scientific evidence will be helpful. It is a question of what kinds of performance count as good management or poor management, and this is a matter of personal taste since the rules of language are flexible enough to allow either judgment in the middle areas. 9

The question might be raised, if competency is determined by reference to a legal standard, why should a physician decide on competency, rather than a court or a jury?

That we do not is attributable to the layman's fear of (mentally ill) persons, his ignorance of mental illness and the resultant abrogation of decision-making duty to the psychiatrist. 10

The United States Senate Special Committee on Aging for 1977 was made aware of this issue in a special report on Protective Services for the Elderly.

The dividing line is drawn by the diagnostician's judgment. This judgment may reflect the observed facts less than the diagnostician's own training, 
experience and attitudes or even the subtle pressures on the physician who is asked by a petitioner to help in committing an elderly, person. For this reason, the diagnostician's opinion, in theory, should be no more than evidence to be weighed by the court with other evidence. 11

The responsibility to decide what kinds of behavior are socially tolerable and consistent with individual freedom must be properly shared by all concerned parties. The role of the social worker is unrecognized by the law. The contribution by the social worker to preserve, enhance and assist toward restoration of the incapacitated individual is, however, unique.

\section{DECISIONS TO SPEND}

The appointed conservator, with support from the Court, may favor savings over a consumptive pattern the aged person may prefer. We need to be aware that at the end of productive years, an aged person may make other decisions about estate expenditures, and not measure behavior against middle-age consumption patterns. The aged rarely have legal dependents, children are past minority and perhaps a spouse is deceased. A lack of responsibilities and the prospect of a short future may affect the decision to consume at a higher rate. The aged tend to be involved in gifts rather than business. They may distribute their entire estate while they are able to enjoy the gratitude of beneficiaries and the tax advantages 
of early dispersal. Conservatorship must not become an effort to conserve for relatives what was to be a fund for the final years. "If evidence of property mismanagement is sufficient for a finding of mental illness (incapacity), preference for individual freedom and decision-making will be defeated."12 If emphasis is placed on property, the real need of the aged--that of adequate personal attention-will be neglected. The point is that a balance of interests must be struck, the balance must favor the individual and his needs in every case.

Because the most pressing need for any incapacitated person is for adequate personal attention, implementation of guardianship and conservatorship must insure protection of the individual's actual needs. The conservator should be permitted to pay out more than the basics to insure the protected person's needs are met. Courts prefer relatives as guardian/conservator over banks or attorneys because of the personal involvement it is expected they have with the individual. In reality, the law provides few guidelines in considering qualifications for appointment. Even failure to make required annual accounting to the court (of the estate, not the whereabouts or conditions of the protected person) is not of itself sufficient grounds for removal of the appointment. According to Alexander and Lewin, a potential heir, named as conservator, may scrupulously conserve the funds for the benefit of the 
protected person. However, in actuality all he is doing is attempting to naximize his own inheritance and, by so doing, deny the protected person enjoyment of his own funds. While we move to protect the individual from possible financial foolishness or fraud, we must be alert to the possibility of self interest on the part of the conservator.

\section{RESTORATION TO COMPETENCY}

Another issue for consideration is that the law generally fails to provide an expeditious method for restoration of competency. Often, much more appears to be required from the petitioner in terms of proof of competency while initially a medical statement may be the essential evidence to provide the court with reason to appoint a guardian or conservator. The statutes do not require the appearance in court by the person to be protected for a legal finding of incompetency or "incapacity." While the statutes say nothing about appearance in court for restoration of competency, there appears to be informal standards. According to available literature, most courts schedule a hearing to be held when such a petition is filed. Not only should the petitioner plan to appear but it is wise to bring character references or witnesses to speak in the petitioner's behalf. A medical statement supporting the presence of competency is also viewed with favor. 
Appointment should be given the same attention as to degree of ability to function as restoration appears to merit. We have a long way to go if the system makes it more difficult to be rid of the burden of incompetency or "incapacity" than to place the stigmatization on the individual in the beginning.

\section{THE LEAST RESTRICTIVE ALTERNATIVE}

Only clear failure to use available income and resources for one's own welfare--such as food, shelter, medicine and medical care--requires intervention by the law. It is suggested intervention on the basis of lesser reasons may constitute abuse rather than proper and protective legal proceedings. In an effort to respond to the challenge, we need to provide wide-spread communitybased services of good quality that encompass a wide range of problems.

There is no substitute for the highest degree of individualization of medical, psychiatric and social casework techniques of assessment of the 'mild, silent sufferers' living in our society. Any service, any therapy, any social plan, is doomed to failure unless it is woven into the longstanding meshwork of both the internal and external environment of the person.13

In this way, the least restrictive alternative to the problem presented would be sought in an effort to maximize self determination. Legal intervention would only be utilized with the clear knowledge that other alternatives 
would not be appropriate in this case. Properly utilized, legal intervention should be considered a constructive and stabilizing force in the effort to maintain persons found to be legally incapacitated, in the community.

The issues in appointment of guardian or conservator must be confronted if one is to be cognizant of the responsibilities. Underlying all aspects of the legal process is the question of how to effect balance between the individual's right to self-determination with the right to protection. The issues selected for discussion are all related to this basic concern. There is latitude available for a wide range of response by those involved. Attention to protection of individual rights must be focused not only at the time of initiation of legal intervention, but during the life of the appointment as well. 
CHAPTER III

HISTORICAL DEVELOPMENT

\section{ENGLAND}

From an historical perspective, guardianship originated in England as an early method of providing care, protection and supervision of minors and the administration of their estates. Prior to 1660, English law provided for feudal as well as borough guardianship.14 Feudal guardianship law had to do with private ownership of land tenures. All of the land was, theoretically at least, held by the King who, on various conditions, granted its use to lords, knights and religious orders; and they in turn granted it to other tenants. This manorial system established a relationship between lord and tenant known as tenure. 15

At the time of the Norman Conquest, obligation to serve in the army was related to status as tenant of the land. At this time, an intricate body of law began to develop by which lords could claim fines and other rights instead of military service. In exchange for service in the army or payments, the lord owed the tenant protection of his person and holdings. 16 As estates became hereditary, they were passed to infants as well as adults. When the 
heir was under age, the lord assumed all decisions relating to the person and holdings until the heir was 21 years of age. Many abuses occurred. Statutes that were enacted later failed to correct the problems.17 The situation of the wards grew more difficult as the feudal system changed from a military organization to a system of taxation. As a result, the feudal system was recognized as failing to realize its purpose.

About the same time borough guardianship allowed the father to make a will appointing a person of his choice to assume custody of the heir and the estate until the ward reached his majority. If no will was made, a public authority, such as a mayor, appointed a guardian. As a result, appointment of guardians by local public officials began to take place. 18 During the later 1600s, both houses of Parliament abolished all tenures and all feudal incidents connected with them. Guardianship by right of tenure was officially substituted by testamentary or statutory guardianship, which had been practiced in the boroughs. Safeguards in administration of estates or supervision of minors were not, however, required by law. The only remedy for abuse was to bring suit after an injustice could be proven. 19

Later English law began to assume responsibility for protection and care of the person and property of the mentally incapacitated as well as decadents and minors. The 
English King, as father of the country (paren patriae), authorized the chancellor who, in response to a petition, would order a judge to inquire whether the individual in question was mentally competent and if he were in possession of assets that might be dissipated. The chancellor began to be viewed as "the keeper of the King's conscience."20 This development actually moved in the direction of modifying earlier testamentary or statutory powers.

Concern with protection of children continued to demand considerable attention in continual modification of the laws. With regard to adults, an incompetent person would be committed to the care of a friend who would receive an allowance from the remaining assets to pay the cost of services and care. Typically, responsibility for management of the assets was assigned to the ward's heir who had to account to the court. 21

It is interesting to note that an inquiry into possible incompetence was held on the basis of there being sufficient assets to conserve. The actual protection of the person was a concern only when linked to significant assets. The law made no provision for care or for custody of the poor who were left to their own resources or to the possible good will of others.

Today's proceedings for legally appointing and holding a guardian and/or conservator accountable are directly linked to this early paternalistic practice in 
England. Most impressive, however, in the history of guardianship in England is the gradual discernible shift of guardianship from a right--profitable to the guardian and often difficult for the protected person--to the point of consideration of the person's welfare as a significantly guiding principle. 22

\section{EARLY AIMERICA}

In colonial America, the same policies prevailed, although development of guardianship was much simpler than in England. The great variety of guardianships were never developed in this country. Many colonies passed laws stating all land would be free of any feudal tenure or wardship. From the beginning in this country, al1 persons were governed by the same laws and presided over by the local courts which were called either probate or orphan's courts.

Persons lacking both in assets and family drifted at the mercy of fortune. Instead of providing for their needs, the ethic of the period, which equated labor with virtue, produced laws that compelled people to work. Those who could not work were obliged to beg. 23

The mentally ill were given more attention than those viewed as simply helpless. Persons who were felt to be too dangerous to be at large were confined by the law, which was the beginnings of our current civil commitment process. During the 18 th century, commitment to a mental institution 
was frighteningly simple, often requiring a single medical opinion. By contrast, appointment of guardianship required a declaration of incompetence, a court petition, with adequate notice and hearing prior to appointment. The law in many basic respects seems unchanged today. The next major step to aid the mentally incapacitated occurred in the 19th century. Dr. Benjamin Rush, Dorothea Dix and others focused public attention on the need for a more humane response to the problems of the incapacitated person. A stream of state legislation followed and constitutes much of the basic legal pattern still in effect today. Civil commitment as well as guardianship law were two primary types of proceedings affected and refined in that period. 24

There is great similarity in state laws and agreement that guardianship be viewed as a probate matter. In the United States, probate law is based on statutes enacted by state legislatures. Probate law cannot, however, be fully understood by reading the statutes alone. The principle of equity is utilized as the basis for interpretation of the law. Equity involves the application of the dictates of conscience or the principles of natural justice in an effort to supplement and remedy the limitations and inflexibility of the law. Equity is usually administered by the courts of original jurisdiction. Before development of large metropolitan areas, there was not enough litigation 
in each county for a full-time judge. This "riding circuit" gave rise to the name of circuit court for the court of original jurisdiction. Because of the nature of probate cases, necessitating the ability to be immediately heard in court, probate matters tend to be placed in local courts which are in session continuously. Probate matters tend to involve a continuing process from initiation, often with subsidiary issues to be determined, until termination. 25

As new states were recognized, guardianship statutes were given priority by early incorporation into state laws. At the same time a realization began to develop that guarantee of rights was a social and public, as well as a private, responsibility. As a result, between 1870 and 1885, several states passed the first bills providing for public guardianship, stipulating that needs not met by regular laws on guardianship would be covered in these statutes. Despite an initial flurry of interest in this issue, only nine states had legal statutes providing for public guardianship by 1935. 26

Typically, a public official would be appointed as public guardian with rights and responsibilities similar to a regularly court-appointed guardian. The appointment was to take place only in the absence of another person willing or able to serve. The statutes indicated the office was to be utilized only as a last resort, and was 
not in any way to seek out wards in possible need of guardianship. The states that did appoint public guardians showed considerable variation in their method of appointment.

\section{THE 1960s}

The years brought many changes in social conditions with few accompanying changes in the law and the way it was administered. During the 1960s, the much-discussed case of Catherine Lake vs. Dale Cameron (Superintendent of a Federal hospital for the mentally ill in the District of Columbia) provided the impetus for a new look at the way in which incapacitated persons were cared for. It was said to represent a landmark in defense of impaired older people.

I believe it is impossible to overstate the significance of the Lake case to the movement for more humane, effective and specific methods for assisting and treating the aged. The Court has held that an aging person, found unable to care adequately for herself but of no danger to anyone else, cannot be involuntarily hospitalized in a mental hospital without full exploration of all possible other alternatives available for her care and treatment in the community. Moreover, the burden is not on the individual, but on the courts to make this exploration. 27

The National Council on Aging was active in bringing into focus the growing attention on the need for community services. In its 1966 conference, the Council discussed future needs. 
In order to assist the impaired older person to live without the harm of neglect and in comfort and security at maximum independence according to his capacity, an effective network of legal, medical and psycho-social services must be provided. To assure a range of preventative, restorative and protective services, new patterns of coordination and collaboration must be initiated so that these protective services become acceptable as a social utility. A vital feature of this service would be that the older person is not looked down upon if he utilizes the service, but that this is an opportunity to help him maintain his right to security and protection throughout his life. 28

Interest in how public guardianship and conservatorship programs could benefit impaired persons expanded as alternatives to institutional care were considered and discussed by persons in the mental health and aging fields.

THE 1970s

A 1977 Working Paper on Protective Services for the Elderly, prepared for the Special U.S. Senate Committee on Aging, reviews some developments in public guardian and conservator programs. The office of public guardian is most often filled by a person appointed by an officer of a state or local government or by the court and is supported by public funds. Several states are said to have established such programs. Examination of each state statute appeared to be the only way of obtaining current information on individual state programs. Because of unfamiliarity with legal language and the time element required to examine individual state statutes, a review of other 
programs for this study was not undertaken.

According to the 1977 Working Paper, California

has the most extensive system.

In California, a county official designated as public guardian is authorized to apply for court appointment as guardian or conservator of the person, the estate, or both, of anyone committed to county mental health facilities, receiving public aid, or requiring assistance but lacking it from any other source.

Following the agency plan, Georgia makes the Commissioner of Human Resources the nominal public guardian for welfare recipients. Maine allows the department of health and welfare to serve as guardian for all 'incapacitated.'

Delaware created a separate state office, headed by a chancellor who is authorized to appoint public guardians. Illinois authorizes the Governor to appoint a public guardian in each county. Oregon permits either the county court or county commissioners to establish the office of guardian.

A court plan, followed in limited fashion in South Carolina, allows the judge of the local court to serve as guardian of an estate if no one else is willing and fit to serve, with compensation the same as for a private guardian. Upon request of a parent, relative, or next friend of the ward, Hawaii allows the clerk of the court to serve as guardian of an estate valued under $\$ 3,000.29$

According to Alabama statutes, if the judge fails to appoint a public guardian, the sheriff may assume the responsibility.

Thus, current practice suggests that the method of selection, the person designated and the jurisdiction of the public guardian/conservator seems to vary widely among the states. It appears the programs are established for 
a variety of purposes encompassing a broad range of persons. These factors would need to be considered in any effort to draw comparisons between individual state programs . 


\section{CHAPTER IV}

\section{DEVELOPMENT OF THE PUBLIC GUARDIAN/CONSERVATOR PROGRAM IN MULTNOMAH COUNTY, OREGON}

Development of the public guardian/conservator program in Multnomah County, Oregon had its roots in Portland's acknowledgment of a need for protective services for those persons unable or unwilling to act in their own best interest. As early as 1964, the Portland Mayor's committee concerned with the elderly discussed consideration of appointment of a public administrator or guardian to act for persons identified as needing someone to act for them. The proposal uncovered a divergence of opinion, particularly among attorneys, on the subject.

\section{EARLY DEVELOPMENT}

During 1965, there was a growing concern about the lack of protective services by many community persons, particularly among social workers and other professionals in the Portland metropolitan area. This concern was, in fact, national in scope. In 1965, Congress enacted the Older Americans Act. This was the first federal initiative to address the psychological and social needs of older persons. "Ageism" began to be taken seriously. 
In that same year, at the first meeting of a newly reorganized and restructured Portland Community Council representing approximately 115 agencies (now known as the Tri-County Community Council), a sub-committee on protective services was established. The sub-committee bégan with a definition of protective services as a basis from which to work. The following is an abbreviated section of the adopted statement:

Protective services are essentially defined as a constellation of services, preventive or supportive in nature, given with the purpose of helping certain individuals to retain or achieve a level of competence and function to manage their own personal affairs or assets or both, to the extent feasible, or with the purpose of acting on behalf of those incapable of managing for themselves.

In short, persons in need of protective service are those who have demonstrated loss in their adaptive capacity in relation to psychological, physical, economic, and social environment.

The identifying element of truly protective service is that there is present a readiness on the part of those rendering such services to use professional authority, readiness to call legal authority into play, or readiness to operate under legal authority or legally sanctioned procedures. 30

As a result of this definition of service, the issue of a program of public guardianship, the extent of need, and how such a program might be administered became one of the specific areas studied by the sub-committee as they examined the unmet needs of the aging population in the Portland area .

After a year and one half of study and discussion, the committee recommended the next phase in this community 
organization effort. Because the problems were so interrelated, complex and broad, a total community approach of education, coordination and cooperation in the form of a workshop was proposed. Friendly House, Inc. (a United Good Neighbor Agency and member agency of the Council) agreed to co-sponsor such a workshop. Mrs. Marion Hughes, as project director, began to shape a project proposal. Funding came from the Oregon State Program on Aging, through Title III of the Older Americans Act of 1965. According to the workshop design, three components were seen as essential in planning: 1) that it be state-wide in participation; 2) that it be interdisciplinary in approach; and 3 ) that it be geared to social action. While all professional disciplines (legal, medical, psychiatric, clergy, social work and psychology) were to be involved in the workshop, social work was recognized as the core of protective services.

Four task force committees were established to research major areas of need. The Social Work and Social Adjustment Task Force report raised the need for a program of public guardianship. Lydia Strnad of Family Counseling Agency articulated the social agency viewpoint. She described how it was almost impossible for agencies to assume such responsibility and as a result, many persons, the elderly in particular, were neglected and often objects of fraud and exploitation. Agencies that recruit volunteers, 
who could be legally appointed as guardian for agency clients, found the method costly and inefficient since new volunteers had to be continually found, oriented and trained. The Legal and Financial Task Force provided a factual compilation of the Oregon statutes relating to guardianships, trusts, commitments and determination of competency. With reference to consideration of public guardian need, the question of whether a "pool of guardians" would be helpful was raised. It was suggested that a state licensing agency might license guardians after specified and required training. It was acknowledged this would require legislative enactment and funding.

In two of the addresses given at the 1967 workshop, Protective Services for Older Adults, Margaret Blenkner, D.S.W., and Edna Wasser, M.S.W.--both of the Benjamin Rose Institute in Cleveland, Ohio, which was pioneering in protective services--raised the subject of public guardianship. In Ohio at that time, public guardianship as an established service was unavailable. A staff member of the institute was, however, legally designated to carry out this function for the institute's clients. Guardianship was seen as an ancillary service to protective services. Availability of legal intervention was seen as critical to the success of many cases. While the issue of public guardianship was articulated in the 1967 Portland workshop, it did not receive sufficient attention or support to result 
in immediate or firm recommendations for action. It was seen as one of many services needing development in order to meet the growing needs of the community.

Ultimately, the overriding concern of the conference became acknowledgment of the overutilization of institutional care in Oregon. It was felt that an improvement in the basic level of available services was needed, as well as development of broad protective services for those in need of such care.

\section{LEGISLATION}

The momentum for development of a public guardianship program did continue to grow. During the 1969 Oregon state legislative session, the first bill calling for the establishment of an office of public guardian was introduced. House Bill 1464 provided for any county to establish and terminate the office of public guardian whenever it determined the need for such an office. The Bill was described as simply enabling legislation and would not require an expenditure of public funds by its passage. A companion bill, Senate Bill 448, eliminated liability of a person signing a petition for guardianship in good faith. In ORS 126.126, which established general guardianship law, the proposed ward was described as either "an incompetent, a minor or a spendthrift." This language was to persist until 1973 when the term "incapacitated individual" was 
substituted by the legislature, tending to reduce the stigma attached to guardianship.

This public guardian legislation was carefully guided through the legislative process until it became law by Senate approval on Friday, May 23, 1969. The single person most responsible for this successful effort was Gerson Goldsmith, Portland attorney, who was acting in his capacity as Chairman of the City-County Council on Aging and as Chairman of its protective services committee. This Council had been established by joint action of the City of Portland and the County of Multnomah to coordinate activities with respect to the numerous problems of senior citizens. The Council consisted of nine members appointed either by the City or by the Board of County Commissioners, with the County Health Officer being an ex officio member. The earlier findings of the 1967 workshop on Protective Services for Older Adults were cited as evidence of the need for guardianship services. Carolyn Hanson, M.S.W., employed by Tri-County Community Council, played an essential role in the compilation of relevant material and case examples supporting passage of the Bill, as well as offering testimony at the legislature. A major step toward establishment of a public guardianship program for the state of Oregon had been taken by Multnomah County. 


\section{IMPLEMENTATION}

By August 1970, a proposal for implementing public guardianship in Multnomah County had been prepared by Roger 01son, M.S.W., of Tri-County Community Council. About the same time a study was also being made of the existing system of social services and court procedures to deal with the allegedly mentally ill older adult. Again, the findings of the 1967 workshop were used to support the need for new approaches. As a result, the process of establishment of a public guardian program and of a protective service program developed concurrently in Multnomah County.

Briefly, the 1970 public guardian proposal defined the need for public guardian of the person or of the estate, for the aged, the mentally retarded or disabled person who was incapable of making competent decisions about his personal well-being and had no friends or relatives willing or able to protect his interests. When such persons refuse help, the only option was felt to be commitment to the state hospital. It was proposed that a short-term pilot project of public guardianship would be an appropriate way of testing an alternative to present practice. The proposal was based on the assumption that guardianship is less damaging to an individual's self-esteem than commitment. It also assumed that commitment to a state hospital is unnecessary for people without psychoses but who are in 
need of a protected environment and management of their personal affairs. It was also assumed that monetary savings would be made to the state of Oregon by preventing unnecessary hospitalization.

Because there was little county money available for new programs at that time and no organized community pressure for implementation, the August 1970 proposal was shelved by the County Commissioners.

TRIAL PERIOD

However, during a December 1970 meeting of Tri-County Community Council, a unanimous decision was reached by participating social service agencies to develop strategy to again bring the proposal to the attention of the County Commissioners. This plan involved political activity in the form of personal contact with members of the County Commission by community leaders, such as agency board members and executives. Letters of support and telephone calls for the proposed program were also marshaled from a wide variety of sources such as the bar association, the Mental Health Association, association for retarded citizens, and the medical society. There were widely differing ideas of the scope of the program ranging from establishment of a major project to a token service. Staffing ideas ranged from appointment of an attorney to merely adding responsibility to an already appointed county 
employee. As a result of this organized and clearly expressed interest and concern, the County Commissioners decided to act. The program was given a six-month trial period to commence in July 1971. It was decided the Assistant Director of Records for Multnomah County would assume the responsibilities of the public guardian. In addition to his on-going duties, Jim Callas was appointed as public guardian for the trial period. Only referrals from social service agencies were to be accepted for possible guardianship during this period.

During December 1971, an evaluation of the trial period was presented to the County Commission. The Portland State University Institute on Aging prepared a descriptive study of the program which was utilized by the acting public guardian and others to request continuation of the program. The report indicated the 25 cases that had been accepted for guardianship came from 13 community social agencies. The 18 women and seven men had an average age of 73.7 years. The most frequently found reasons for referral were described as mental confusion, requiring assistance with personal care or supervision, physical illness or disability as well as being in danger of financial exploitation. Two conclusions were drawn from the report. First, in a majority of cases, it was felt the use of public guardianship was clearly instrumental in helping to prevent continuing deterioration 
or financial exploitation. Secondly, the vital role played by social services was felt to be essential to a successful public guardianship program.

\section{PROGRAM ESTABLISHMENT}

On December 30, 1971, M. James Gleason, then Chairman of the Multnomah County Board of Commissioners, authorized the actual establishment of the first office of public guardian in the state of Oregon. See Appendix A for a copy of the original order. This order was to take effect January 1, 1972 making Multnomah County the first, and to date the only, Oregon county to act on the 1969 provisions of HB 1464 establishing public guardianship.

Concerns with coordination, mutual planning with social service agencies, as well as formalizations of program procedures were ongoing issues in the first several years of operation. Jim Callas continued to hold the position of public guardian until late 1973. During January 1974, Paul Nizdil, who came to the position with a background of work in Juvenile Court, assumed responsibility of the office and continues in that role today.

\section{LEGISLATIVE CHANGES}

In 1973 the legislature instituted changes in the guardianship statutes by adopting the language of the Uniform Probate Code. The term "incapacitated" was 
substituted for "incompetent or spendthrift." "Conservator" was designated to mean a person appointed to administer the estate of a protected person while "Guardian" means a person appointed as guardian of a minor or incapacitated person.

\section{VETERAN'S PROGRAM}

Veterans as a group are subject to special legislation. Although the Veteran's Uniform Guardianship Act was passed as federal legislation in 1924 to be ratified by the states, only 24 states have chosen to adopt the Act. Oregon chose to enact its own legislation. By statutory authority, ORS 406.050(5) provides:

The director of the Veteran's Administration shall have the authority to act without bond as conservator of the estate of a beneficiary of the V.A. when he determines no other suitable person will so act.

In January 1978, according to the Department of Veteran's Affairs, there were 131 conservatorships in Multnomah County and a total of 463 in the entire state of Oregon. There is no provision for guardianship of the person in the statutes by the V.A. If such intervention is required, relatives, friends or the public guardian's office is utilized. Determination of the need for conservatorship is made by an adjudication group within the V.A. Request by the veteran or others, medical evidence, and contacts with the V.A. by the person in need of protection are considered by a panel of experts to determine need for 
conservatorship. Most V.A. conservatorships involve small estates as well as those in need of assistance with social problems .

\section{COORDINATION WITH COMMUNITY}

During this time, activity in development of services to the elderly continued. Project ABLE (A Better Life for the Elderly), established in May, 1972, was funded by the Older Americans Act, Title III and administered through contractual agreements with the City-County Commission on Aging. This program was to address the needs of persons over age 60 and was to be an area-wide model for coordination of services to the elderly. Project ABLE had seven components. These components included counseling and referral, transportation, legal services, geriatric screening, nutrition, homemaker and analysis. Since Project ABLE was charged to address the problem of limited alternatives to institutional care in Multnomah County, the public guardian program became a valuable resource by providing the needed legal structure necessary to maintain specific individuals in the community. From the beginning of Project ABLE, the public guardian worked closely with the geriatric screening service as both programs frequently served the same client. Geriatric screening had been specifically directed to provide social 
services to the most frail and disabled elderly group in the county.

During its establishment and tenure in the Multnomah County Public Health Department, geriatric screening changed its name to protective services. In 1974, Project ABLE was absorbed into a new structure called the Area Agency on Aging, mandated by the federal government, and administered by the City of Portland through an agreement with Multnomah County. Protective services moved to the Metropolitan Family Service agency in October 1974, and services to the frail and disabled elderly continue to be delivered from that agency today. The relationship between the public guardian/conservator and protective services can be termed reciprocal. Because of the specialized services each program offers, clients who require attention from both are often those who may successfully remain in the community.

It is important to mention that while a considerable number of the persons served by the public guardian/conservatorship program are in the over-age-60 category, there is also a significant number of younger adults and some minors in the program at any one time.

The following chapter will examine the current program of public guardianship and conservatorship in Multnomah County. The characteristics of the population served will be reviewed as well. 


\section{CHAPTER V}

THE CURRENT PROGRAM OF PUBLIC GUARDIANSHIP AND CONSERVATORSHIP IN MULTNOMAH COUNTY, OREGON

LEGAL BASE AND GENERAL POLICY STATEMENT OF PROGRAM

Title 13 of the Oregon Revised Statutes, Chapter 126, contains the law pertaining to Guardianships, Conservatorships, and Gifts to Minors. ORS 126.003 through 126.965 provides specific statements on each aspect of the law. Included are General Provisions as pertaining to Guardianships and Conservatorships, Guardianships of Minors, Guardianships for Incapacitated Persons, Protection of Property of Minors and Incapacitated Persons, Conservators, Payment of Claims, Miscellaneous and Gifts to Minors. ORS 126.905 through 126.965 pertains specifically to Public Guardians and Conservators. The complete text of these statutes relating to the legal aspects of Public Guardianship and Public Conservatorship are quoted in their entirety in Appendix A.

The Public Guardian/Public Conservator program is charged with the responsibility to provide public protection of Multnomah County residents declared legally incapacitated by the Probate Court. Public guardianship or conservatorship or both are to be provided to persons whose inability 
to handle personal or financial affairs can be documented. Other resources such as family or friends must be determined to be unavailable or unable to serve before public protection is considered.

Without intervention, the social/psychological and economic impact on legally incapacitated persons is often devastating. Such persons are vulnerable to fraud, exploitation, and loss of resources. They are often unable to maintain reasonable social standards of self-care and conduct sufficient to avoid jeopardy to health, safety, comfort or property of self or of others.

The services of a public guardian and conservator, in conjunction with supportive and protective community social services, attempt to maintain such legally incapacitated persons in the community. Services are tailored to individual needs, capacity to cope, and ability to deal realistically with living in the community. While some forms of institutional care, such as group living situations or nursing home facilities, may be the most appropriate form of care for an individual, all efforts are directed toward maintaining a person in the community wherever possible. Thus, institutionalization may be avoided with fewer costs to the individual as well as to the community. 
LEGAL DEFINITIONS AND PROCESS IN ESTABLISHMENT OF GUARDIANSHIPS AND CONSERVATORSHIPS

Briefly, the central objective of the program is to provide conservatorship of the estate and/or guardianship of the person services for those legally designated as in need. "Incapacitated person" means a person who is unable, without assistance, to properly take care of himself or his personal affairs. "Guardian" means a person appointed as a guardian of a minor or incapacitated person. "Conservator" means a person appointed as a conservator to administer the estate of a protected person. "Ward" is a person for whom a guardian has been appointed (ORS 126.003).

Requests for legal intervention may come from community social service agencies, medical and health facilities, families, friends, private or corporate conservators, or from the court itself.

The need for protection must clearly exist and be documented. A written request from the referring agency or person, reviewing the reason for referral, the current situation, information about significant others, medical, financial, and legal is pertinent. Not only must the need for legal intervention be established by someone knowledgeable about the person, but the ability to work with the individual in the future can be facilitated by such information. A current medical report, including a 
statement by the physician relating to the person's ability to manage his own affairs, is required by statute (ORS 126.103).

Available written reports are filed with the petition, which is signed by the public guardian and conservator. Whenever possible, the person to be protected will be asked to sign the petition as well. Personal contact is made by the public guardian and conservator with the person to be protected for the purpose of clarification and explanation of the petition. A special delivery mailing is sent to the person if personal contact is not possible. Notice of the petition is mailed to any known family members and all other interested people (ORS 126.007).

If objections to the petition are filed, a court hearing is scheduled to hear the objections. Otherwise, the order establishing guardianship or conservatorship or both is signed by the Probate Judge at the end of the period of notification.

Termination requires another petition to be filed with the court with supporting evidence of the reason.

During December of 1977, a study of the tasks and functions of the Multnomah County Office of Public Guardian and Conservator was undertaken (see Figure 1 for a flowchart of that program's process). Significant tasks will be mentioned from more general job descriptions which have been adapted from ORS 126.003 through 126.965. When 


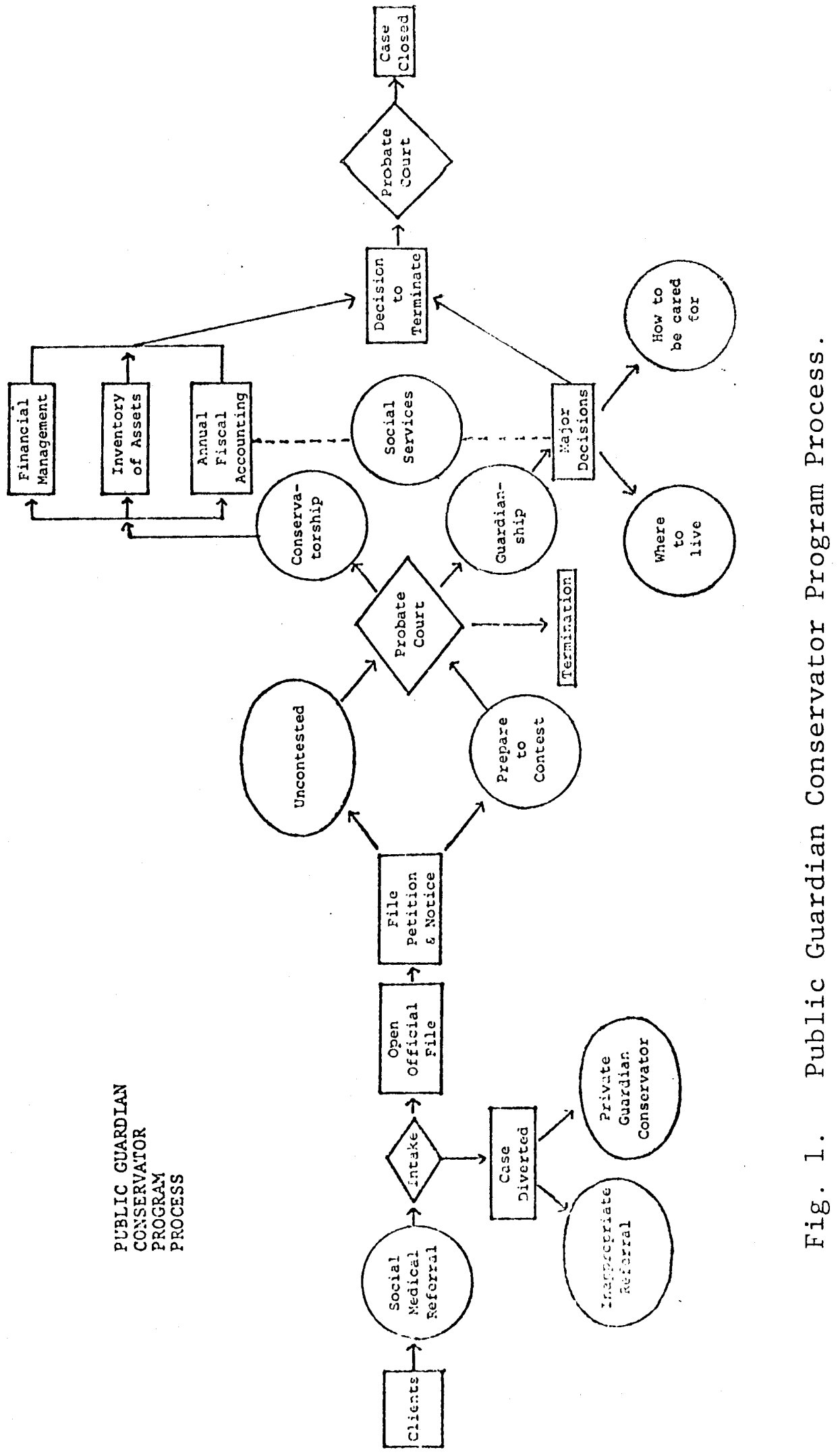


appropriate to a discussion of a task performed by the staff, and for the sake of specificity, precise or exact statutes will be cited.

\section{STAFF}

At the time of this study, the staff consisted of two secretarial persons, a part-time accountant, and one appointed public guardian/conservator. The secretarial staff perform a variety of functions under the direction of the public guardian/conservator such as preparation of legal petitions, annual and final accountings as well as complete inventories to be made to the court, and establishment and maintenance of individual files. A research of assets on all conservatorships is conducted by mail. Over 100 sources of financial holdings--such as banks, credit unions, and savings and loan associations--are contacted. At the conclusion of such a search, all funds are placed in one trust account which is then invested by the public conservator (ORS 126.945).

Under the direction of the public guardian and conservator, the accountant receives and documents all collections of individual sources of income and benefits due as well as addressing all claims and debts (ORS 126.313). He is responsible to maintain a subsidiary ledger which separates clients' funds. The accountant assists the public conservator to prepare an initial inventory of 
property and assets to be filed 90 days after the order establishing conservatorship (ORS 126.277). An annual accounting is also made to the Probate Court detailing dispersal of funds in the preceding year (ORS 126.283).

The role of the public guardian/conservator is extremely varied and demanding. In order to fulfill the responsibility of the office, the public guardian/conservator must be attuned not only to the legal responsibilities of the program, but must be able to respond to each person as a human being requiring special and individual attention. A fuller description of the role of the public guardian/ conservator outside of his legal responsibilities will be provided in the next chapter with a discussion of auxilliary services.

Activities of the public guardian/conservator may include attendance at court hearings, meetings and appointments with professional persons and a variety of community people on behalf of the person being protected. Agency consultations, both in and out of the office, are held as well as necessary contacts with the protected person, usually in his residence, as many are physically unable to keep an office appointment. In addition, on an average of once a day, in person or by telephone, consultations are provided to citizens who are considering guardianship or conservatorship for others or for themselves. These may be brief and result in referral to another agency, or they may require 
some follow-up by the public guardian/conservator to assist the situation toward resolution. They all require time and a knowledge not only of the law but of community resources to be explored prior to the filing of a petition. Legal consultation is available to the public guardian through the county counsel.

\section{PUBLIC GUARDIANSHIP}

Guardianship of the person is established when there is significant evidence that the person to be protected is unable or unwilling to make critical decisions for himself, usually having to do with where he is to live or be cared for. Guardianship is usually considered to be a drastic step, a last resort, and is generally justified on the theory that such action protects the ward, or the community, or both.

Essentially, guardianship of the person is "like the relationship of a parent to the child" without the liability a parent has for his child. The guardian becomes responsible in areas in which the ward is no longer able to act responsibly (ORS 126.137).

In December 1977, there were 43 active cases of public guardianship, 17 of which were also protected by conservatorship. The reasons for establishment were many. They frequently had to do with the inability of a severely incapacitated person to make a major decision, such as allowing 
emergency medical care in which case a temporary guardian may be immediately appointed for a specified period and purpose (ORS 126.133). They were also frequently established in order to move a person from a hazardous living situation and/or to assure maintenance of an individual in a protected setting.

A case example involved a single woman, age 57 , who had, at a much younger age, received a prefrontal lobotomy while being treated for mental illness in a state institution. This treatment left her somewhat child-like. While she exhibited very little of her previous emotional swings, now she tended to withdraw and retreat from activities in the real world. Any break in her rather rigid routine and approach to living was disturbing. Because of suspicious physical symptoms, Miss M. was admitted to a hospital for a needed examination. The examining physician suspected the possibility of cancer and felt immediate exploratory surgery to be essential. Miss M. totally refused, dismissed the physician's explanations, and remained inappropriately unconcerned about her future. All attempts to persuade her were fruitless. Because the situation was felt to be potentially lifethreatening, a request for temporary guardianship was made. Such temporary guardianship was granted, the public guardian signed the consent for surgery after determining such action was warranted, and the operation commenced with the result that the condition was less than cancer, but one that did require medical treatment to cure. Miss $M$. is now back in the community and temporary guardianship has been terminated.

While the need for guardianship is usually not emergent and can await the 10-day period of notice, in some cases the need is even more pressing. On occasion the Probate Judge and the public guardian have, at the request of a physician, gone to a medical facility, heard the necessary 
evidence, and granted temporary guardianship in order to facilitate life-saving medical care.

\section{PUBLIC CONSERVATORSHIP}

Conservatorship is established most often for those persons with small estates who are without relatives or friends willing or able to serve. Despite the usual small estates of the protected person, there may be considerable work involved in putting complicated affairs or assets that may be in great disarray into reasonable order. Bonding of the public conservator is required (ORS 126.935). For Multnomah County, the public guardian/conservator's bond is $\$ 100,000.00$.

Perhaps the most essential aspect of conservatorship is for the reasonable expenditure of available funds to be made for the benefit of the protected person (ORS 126.317) who may be unable or unwilling to utilize funds for his own benefit.

As conservator and legal representative of the protected person, there are a number of expectations to be fulfilled as required by a particular estate. These include, but are not limited to: collection of all sources of income and benefits due, addressing all claims and debts, investing funds, conducting an inventory of all possessions, repairing of property, entering into contracts on behalf of the protected person such as leasing property, arranging 
appraisal and sale of property, as well as litigating claims on behalf of the protected person. Title to the assets of the estate remains in the protected person's name, but all legal action with regard to the assets is taken by the conservator. In other words, the protected person no longer has the capacity to enter into any contract except through his conservator (ORS 126.313).

Whenever possible, the protected person is consulted and involved in decisions of management of the estate. At the discretion of the conservator, a protected person can control and manage various assets of the estate in accordance with his ability to do so.

A nominal minimum fee is charged for all conservatorships. Any additional fee is contingent upon the total assets of the estate and is based on a sliding fee scale (ORS 126.955).

In December 1977, there were 72 active cases of public conservatorships, 17 of which were also protected by guardianship. The basic reason for establishment had to do with the inability, either physically or mentally, of the protected person to make apparent rational decisions regarding his financial affairs.

As an example, a 78-year-old widow was referred for conservatorship by a social agency. Mrs. A. lived alone in her own home where it appeared that she failed to cook properly for herself and rarely attended to any housework. With the assistance of a social worker and a good neighbor of many years, she agreed to receive daily Meals-on-Wheels 
and bi-weekly homemaker service. Daily telephone contact was maintained by an elderly friend. Mrs. A. had never had a checking account. She cashed her monthly Social Security check at a loca! bank and walked home with the cash. For many months, the neighbor assisted Mrs. A. in paying bills until Mrs. A. came to totally rely on the neighbor. The neighbor had an ill husband, worked full-time, and felt increasingly burdened by Mrs. A.'s needs. Because Mrs. A. was also forgetful and sometimes confused, she began to hide her money in the house. Mrs. A. began to pay for prescriptions at the local drug store by leaving the key to her house on the counter. She attempted to give the doctor's receptionist her savings pass book. Mrs. A. had become a possible target for exploitation. At this point, public conservatorship was established, and Mrs. A.'s financial affairs were properly handled and protected for her use. Mrs. A. successfully remained in her own home until a severe heart attack created the need for nursing home care. Her financial needs continue to be met by the public conservator's careful handling of her resources. Social work services have continued as well.

\section{PHYSICAL PLANT}

The public guardian/conservator's program has always been located in the Multnomah County Courthouse. This location, which is in close proximity to the court and the county clerk's office, greatly facilitates the legal aspects of the requirements of the program.

Space is a growing concern for many of the services located in the Courthouse. For the public guardian/conservator, it has become a critical issue. Three full-time and one part-time staff occupy one room 12 feet by 11 feet. One end is partitioned off as a semi-private office for 
the public guardian/conservator. Necessary office equipment leaves little extra space. Multnomah County's Department of Human Services has a list of priority items to be addressed the next fiscal year; more adequate space for the public guardian/conservator's program is one of the items.

\section{BUDGET}

Most of the budget of the public guardian/conservator's program is allocated for staff salaries. Approximately one-third of the budget resources come from conservator's fees charged to individual estates handled by the program. The remainder is supplied by Multnomah County Department of Human Services.

For fiscal year 1976-77, the budget was as follows: Personal services (all staff \& fringe benefits) $\$ 63,899.00$

Professional services (needed consultations) 755.00

Printing and reproduction 300.00

Communications 830.00

Postage 425.00

Office supplies 400.00

Minor equipment and tools 89.00 Building Management Services $1,700.00$ Equipment $2,000.00$ TOTAL BUDGET: 


\section{CHARACTERISTICS OF POPULATION SERVED}

By definition of the law, all persons receiving public guardianship and conservatorship services are "incapacitated." In an effort to understand the meaning of the legal term, a study of the December 1977 active cases was undertaken. The data suggests wide differences exist between those individuals who require legal intervention. They do, however, have a common need for someone to act for them in the areas they are unable to, with some degree of competence, act for themselves. See Appendix A for a copy of the letter requesting permission to examine agency data.

The tables which follow are used to present data from 98 active cases.

\section{TABLE I}

MARITAL STATUS OF MALE AND FEMALE PROTECTED PERSONS, BY NUMBER AND PERCENT

\begin{tabular}{|c|c|c|c|c|c|c|}
\hline & \multicolumn{2}{|c|}{ Males } & \multicolumn{2}{|c|}{ Females } & \multicolumn{2}{|c|}{ Total } \\
\hline & 韭 & \% & 非 & $\underline{\%}$ & 韭 & \% \\
\hline $\begin{array}{l}\text { Married } \\
\text { Widowed } \\
\text { Single } \\
\text { Divorced/Separated } \\
\text { Unmarried couple } \\
\text { Unknown }\end{array}$ & $\begin{array}{r}3 \\
4 \\
10 \\
12 \\
1 \\
15 \\
45\end{array}$ & $\begin{array}{r}7 \\
9 \\
22 \\
27 \\
2 \\
33 \\
100\end{array}$ & $\begin{array}{r}3 \\
31 \\
5 \\
8 \\
1 \\
5 \\
53\end{array}$ & $\begin{array}{r}6 \\
58 \\
9 \\
15 \\
2 \\
9 \\
99 \%\end{array}$ & $\begin{array}{r}6 \\
35 \\
15 \\
20 \\
2 \\
20 \\
98\end{array}$ & $\begin{array}{r}6 \\
36 \\
15 \\
20 \\
2 \\
\frac{20}{99} *\end{array}$ \\
\hline
\end{tabular}

*Total does not equal 100 due to rounding.

According to Kammerman and Kahn in Social Services in the United States, in 1974 most older women were widows 
(52 percent, or 12.8 million). There are also four times as many widows as widowers with most older men married (79 percent, or 9.2 million) and living with their wives. 31 In this program, women are significantly grouped as widows with the status of men scattered between single, divorced or separated, or unknown to the writer.

A review of active cases indicates that protected persons ranged in age from 10 to 95 with the majority being over age 60. Table II shows more older women than men, both in number and percent.

\section{TABLE II}

AGE RANGE AND SEX OF PROTECTED PERSONS, BY NUMBER AND PERCENT

\begin{tabular}{|c|c|c|c|c|}
\hline \multirow[b]{2}{*}{ Age Range } & \multicolumn{2}{|c|}{ Males } & \multicolumn{2}{|c|}{ Females } \\
\hline & 韭 & $\underline{\%}$ & 韭 & \% \\
\hline $\begin{array}{r}0-20 \\
21-30 \\
31-40 \\
41-50 \\
51-60 \\
61-70 \\
71-80 \\
81-90 \\
91-100\end{array}$ & $\begin{array}{r}4 \\
2 \\
7 \\
1 \\
2 \\
13 \\
6 \\
6 \\
4 \\
45\end{array}$ & $\begin{array}{r}9 \\
4 \\
16 \\
2 \\
4 \\
29 \\
13 \\
13 \\
9 \\
99 *\end{array}$ & $\begin{array}{r}1 \\
4 \\
2 \\
1 \\
4 \\
12 \\
15 \\
11 \\
3 \\
53\end{array}$ & $\begin{array}{r}2 \\
8 \\
4 \\
2 \\
8 \\
23 \\
28 \\
21 \\
6 \\
102 *\end{array}$ \\
\hline
\end{tabular}

*Total does not equal 100 due to rounding.

Legally incapacitated persons under age 60 compose 29 percent of the total surveyed; 71 percent are concentrated in the over-age-60 group. 
TABLE III

AGE CLASSIFICATION OF TOTAL CASES UNDER

AND OVER AGE 60 AND SEX, BY

NUMBER AND PERCENT

\begin{tabular}{|c|c|c|c|c|c|c|}
\hline & \multicolumn{2}{|c|}{ Males } & \multicolumn{2}{|c|}{ Females } & \multicolumn{2}{|c|}{ Total } \\
\hline & 韭 & $\underline{\%}$ & 韭 & \% & 韭 & \% \\
\hline Under age 60 & 16 & 36 & 12 & 23 & 28 & 29 \\
\hline Over age 60 & 29 & 64 & 41 & 77 & 70 & 71 \\
\hline & 45 & 100 & 53 & 100 & 98 & 100 \\
\hline
\end{tabular}

According to Kammerman and Kahn, there were 22 million Americans aged 65 and over with the fastest growing group among those elderly aged 75 and over. Most older people (12.8 million) are women. 32 The group served by the Multnomah County program tends to reflect the national characteristics of the aged.

The current guardianship/conservatorship active cases were viewed as to year of appointment. See Table IV. It was found that one case of the original 25 during the "six month trial period" in 1971 is still active. Appointment of conservatorship is significantly higher than the others. This may be related to increased ability of referring agencies to assist the client to act voluntarily in his own behalf.

Many estates are under $\$ 20,000.00$, with the majority under $\$ 10,000.00$ in total assets. Table $\mathrm{V}$ provides a view 
TABLE IV

YEAR AND TYPE OF APPOINTMENT, BY NUMBER

Year of Appointment Guardianship Conservatorship Joint

1971

1972

1973

1974

1975

1976

1977

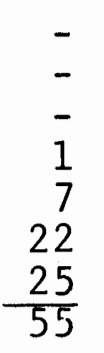

$\begin{array}{r}1 \\ 1 \\ 7 \\ 2 \\ 2 \\ 3 \\ 3 \\ \hline 17\end{array}$

TOTAL :

$\underline{98}$

of assets inventoried on 72 active conservatorship files as of December 31, 1977.

TABLE V

LEVEL OF TOTAL ASSETS OF ACTIVE CONSERVATORSHIPS, BY NUMBER AND PERCENT

\section{Estate Size}

Below $\$ 10,000$

$\$ 10,000$ to $\$ 19,000$

$\$ 20,000$ to $\$ 29,000$

$\$ 30,000$ to $\$ 39,000$

$\$ 40,000$ and above

TOTALS
非

$\%$ 
Because of the many influences on property values, it is difficult to state conclusively the total value of assets of those under conservatorship at any one time. Many older people own at least their home. Public conservatorship accepts only small estates.

\section{TABLE VI}

TOTAL SOURCES OF INCOME OF ACTIVE CONSERVATORSHIPS , BY INUMBER

AND PERCENT

\begin{tabular}{lrr}
\hline \multicolumn{1}{c}{ Source } & \# & $\%$ \\
\hline Social Security & 56 & 45 \\
Private Pensions Services & 25 & 20 \\
Adult and Family Servicincome & 14 & 11 \\
Supplemental Security Incolity & 13 & 10 \\
Social Security Disability & 10 & 8 \\
Workman's Compensation & 3 & 2 \\
Trust Fund and Inheritance & 2 & 2 \\
Rental & -125 & 100 \\
\hline
\end{tabular}

Several individuals have a combined income of two or more sources. Social Security may be supplemented by Supplemental Security Income as an example. The high number of persons receiving pensions reflect the number of longterm occupations held prior to the period of incapacity. Some persons are eligible for additional benefits which the conservator can apply for in their behalf.

At the time of appointment, 59 percent were in independent living arrangements and 41 percent in hospitals or 
TABLE VII

LIVING ARRANGEMENT OF PROTECTED PERSONS AT TIME O $\vec{F}$ APPOINTMENT AND AT TIME OF FIRST ANNUAL ACCOUNTING TO THE COURT, ONE YEAR LATER, BY NIJIBER AND PERCENT

\begin{tabular}{|c|c|c|}
\hline Living Situation & $\begin{array}{l}\text { At time of } \\
\text { Appointment }\end{array}$ & $\begin{array}{c}\text { One year } \\
\text { Later }\end{array}$ \\
\hline & $\underline{\%}$ & 韭 \\
\hline
\end{tabular}

\begin{tabular}{lrrrr} 
Own Home or Apartment & 33 & 34 & 26 & 26 \\
Hospital & 31 & 32 & 6 & 6 \\
Protected Living & 15 & 15 & 22 & 22 \\
Hotel & 10 & 10 & 8 & 8 \\
Nursing Home & 9 & 9 & 36 & 37 \\
\multicolumn{1}{c}{ TOTALS } & 98 & 100 & 98 & $99 *$
\end{tabular}

*Total does not equal 100 due to rounding.

nursing homes. A year later, there are 56 percent in independent living with 43 percent in nursing homes or hospitals. Several shifts may have occurred for an individual with the goal of finding the living arrangement most suited to his physical and mental capacities. Protected living arrangements include homes for the aged, retirement homes, and adult foster homes. Many persons fear institutionalization. This data reflects essentially the same level of independent living is experienced one year after appointment. Protected persons are not denied their own living arrangements .

of the 98 individual cases reviewed, 91 persons are Caucasian and seven of minority race. This balance is 
reflective of the County population. Twenty-two individuals were, or had been, parents to 45 children. However, of the persons who had them, most relatives did not live in the area or are elderly or ill themselves, or, for other reasons, are unable to act as guardian or conservator or to assist. Fifteen individuals had or currently have about 55 pets, usually cats and dogs or sometimes such exotic pets as rats, possums, or birds. The importance of pets to impaired persons should not be overlooked. Isolated, homebound persons have less human contact and use pets as a substitute which is healthier than no contact at all with any living object. A pet gives them a living object to care for, feed, enjoy, and may in some ways become their reason for living.

Occupations (presently all are either retired or incapacitated and unable to be employed) reflect a wide range of experiences from hotel management, clerking, accounting, seamstress, carpenter, cowboy, waitress, school teacher, military career, circus performer, salesperson, and longshoreman. Many have had colorful and interesting careers prior to becoming incapacitated. Some persons have had no occupation due to early and severe incapacity.

At the time of referral and acceptance by the court for protection, the 98 clients, according to available medical reports and behavioral descriptions, exhibited a wide range of incapacity. The following numbers reflect fewer actual conditions of this group due to incomplete or 
partial information. In addition to those listed, there is often significant depression and/or anxiety present as the person may experience great stress in his inability to function. The condition of the frail, often mentally and socially isolated, impaired elderly at the time of referral can be shocking. They may no longer be able to care for daily needs, they may be subject to abuse, neglect, disease, accident, and exploitation because they have no family or friends to assist them. Such conditions have produced a person unable and often unwilling to use resources, either his own or those in the community. In some instances, however, one severe condition such as retardation may, in particular circumstances, be the single overriding reason for needed legal protection.

\section{TABLE VIII}

MEDICAL/SOCIAL CONDITIONS NECESSITATING LEGAL INTERVENTION AT TIME OF CLIENT REFERRAL, BY NUMBER AND PERCENT

Condition*

Chronic physical illness

History of psychiatric hospitalization

Living in hazardous/harmful conditions Defective judgment Alcoholism

Victim of exploitation by others Blind and/or deaf

Requiring emergency intervention Retarded

Victim of disabling accident

韭 $\quad$

31

28

24

18

11

11

10

3
64

33

32

29

24

18

11

11

10

3

*Most individuals were affected by more than one condition. 
Although Table VIII describes 98 individuals, many are listed more than once due to the presence of more than one serious disabling condition. While the number of persons with chronic physical illness is high, most were coupled with functional incapacity as well, such as impaired and fragmented memory systems which, when serious, may result in a breakdown of cognitive processes such as judgment and insight. Although none of these categories are mutually exclusive, they do provide one with a sense of a seriously impaired person in need of reliable and sustaining outside help in order to cope with life stresses.

\section{TABLE IX}

DEGREE OF MOBILITY OF TOTAL PROTECTED

PERSONS, BY NUMBER AND PERCENT

\begin{tabular}{|c|c|c|c|}
\hline Degree of mobility & & 韭 & $\underline{\%}$ \\
\hline \multirow[t]{2}{*}{$\begin{array}{l}\text { Confined to bed } \\
\text { Must use wheelchair } \\
\text { Semi-ambulatory } \\
\text { Ambulatory }\end{array}$} & & $\begin{array}{r}9 \\
18 \\
39 \\
32 \\
\end{array}$ & $\begin{array}{r}9 \\
18 \\
40 \\
33 \\
\end{array}$ \\
\hline & TOTAL: & 98 & 100 \\
\hline
\end{tabular}

Semi-ambulatory includes dependency on a cane, a walker, another person to assist in the case of blindness or being unable to fully utilize motor abilities due to physical incapacity. The degree of mobility may be tied to the presence of a chronic condition and may or may not be associated with age. 
Legal intervention sometimes enabled a person near the end of life to secure certain necessities and greatly desired benefits. It also relieves family, friends or professional persons of frustration and guilt of leaving a person untended and in danger. The positive as well as the potential negative benefits must constantly be weighed.

The presumed beneficiary may often be resentful and perhaps further alienated by legal intervention. It is critical to involve each person from the beginning of the contemplated legal action and help them to understand the benefits that may be possible. The stigma of court wardship along with the loss of liberty, civil rights, and pride can be devastating. The way in which the entire situation is handled by all involved is critical for the protected person.

Most importantly, those persons who are seriously non-functioning individuals in the community may be afforded the opportunity previously denied to the same, to remain in the community. The provision of special legal intervention coupled with ongoing and sustaining services can make the difference.

A typical case of incapacity has been constructed from data taken from active case records:

Based on dominant client characteristics, a typical person served by the public guardian/ conservator program is female, widowed and between the ages of 70 and 75 . Reasons for referral most commonly are inability to handle personal and financial affairs due to deteriorating functioning. Chronic and severe physical 
or mental illness unmanaged by regular medical care, in combination with deteriorating social conditions, are the overwhelming reasons for legal intervention.

This person lives alone in her own home, where she is unable to make needed repairs or maintain usual housekeeping standards. Mobility is limited. Income is small and fixed. Relatives have been outlived or alienated. Because of advancing age, unstable physical and mental conditions, there is gradual withdrawal and isolation. Pets take on great significance. Nutritional needs are neglected due to inability to shop, lack of interest in cooking, and eating alone. Without outside help, conditions continue to deteriorate. The result is a person living in a hazardous or harmful condition, becoming a vulnerable victim for exploitation, or developing a crisis in physical or mental functioning requiring emergency intervention.

\section{SELECTED CHARACTERISTICS OF CLOSED CASES}

A survey of the program's closed records from July 1971 through March 1978 was made. Basically the survey was designed to determine reasons for case closure. The closed file population totals about 400 cases. Approximately 100 files were found to contain informal work completed during the screening process and closed prior to the filing of a formal petition. This survey was designed to sample only those records in which a petition had been filed with the court. The actual population sampled was 300 closed records. A random sample of 154 files was drawn from the 300 records that meet the criteria of the survey design.

This sample size meets or exceeds a plus or minus five percent error rate at the 95 th level of confidence. In other words, 95 times out of 100, one can expect no more 
than a five percent variance from the general population. Statistical summaries of the data on closed records are found in Appendix B.

Since the outset of the program, there has been two administrations. In interviewing program and court personnel it has been determined there have been differences between the two administrative practices. There is reason to believe the causes for closure varied between the two administrations. However, this study was not designed to determine differences between the two periods. One of the areas most affected by the change in administrations appears to be the category of return to competency. The current administration has instituted a thorough screening process which has reduced the possibility of inappropriate petitions.

No attempt was made to correlate variables of age, sex, referral source, provider of ongoing social services and reasons for termination with the number, type and year of appointment.

Of the 154 case samples, 90 were female and 64 male. A higher number of females wereconsistently served by the program (see Table XI in Appendix B).

of the 105 joint appointments, 88 were made prior to 1974. The change in the language of the law provided for options in appointments after that time. After 1974, the type of appointment is fairly divided (see Table XII in Appendix B). 
Referrals came from 19 sources although hospitals, Metropolitan Family Service, and Adult and Family Services Division referred significantly greater numbers. Forty-six, or about one third of the files, contained no information about who had made the initial referral. While a correlation between files with written referrals and year of appointment was not part of the survey design, such files tended to originate in the early years of the program. Ongoing services were documented as being provided in 67 cases. However, 87 files made no mention of ongoing services being provided (see Table XIII in Appendix B).

There were 13 separate reasons for termination. Death of the individual was recorded as the reason in 51 cases. Referral to private guardian or conservator occurred in 35 cases. Adult and Family Services Division assumed responsibility in 28 cases. Restoration to competency occurred in 16 cases. The remainder were scattered between nine other reasons (see Table XIV in Appendix B). Closed records were studied for average length of appointment time. Guardianship appointments average 7.7 months. Conservatorship averaged 10.9 months and combined appointments average 14 months.

The conclusions drawn from this survey are that almost all referrals prior to 1974 resulted in establishment of an appointment. There is no evidence of screening with a search for existing resources prior to filing of the 
petition. The main conclusion is that the early program failed to establish standards and maintain consistency in its response to referrals. The lack of guidelines and procedures for service seems to be reflected in all phases of case handling. Later records supply significantly contrasting data. Referrals are more complete. There is evidence of coordinated planning for ongoing services. A more organized and responsive approach is apparent.

\section{CONCLUSIONS ABOUT ENTIRE POPULATION} SERVED BY PROGRAM

Based on analysis of all data, more than 70 percent are over the age of 60 . In the over-age-60 group, the percentage of females is higher by 13 percent.

Prior to 1974, all appointments were guardianship of both the estate and the person, as required by the language of the law. In 1973 the law provided for either guardianship or conservatorship. Current open cases reveal twice as many conservatorships as guardianship appointments with the fewest in combined appointments. Fewer guardianships may possibly be accounted for by the increasing ability of social services to intervene at a point in which the client decides to voluntarily make decisions in his own behalf.

As the community becomes aware of the program, the trend is for gradually increasing numbers of referrals. The ability to efficiently handle a growing number of 
referrals is essential. Well researched and documented referrals from community agencies make the task easier and allow more time to be invested in providing actual service. According to the closed files as well as active records, three organizations have been major referral sources. Area wide hospitals, Metropolitan Family Service, and Adult and Family Services Division refer far more individuals than other agencies. In addition, Metropolitan Family Service has, throughout the program, acted as the primary service provider offering protective services for ongoing cases requiring social services (see Table $X$, and Table XIII in Appendix B). The following chapter will focus on ancillary services and discuss how such services, in cooperation with legal intervention, may make it possible for severely incapacitated persons to be provided options previously unavailable. 


\section{CHAPTER VI}

\section{ANCILLARY SERVICES}

The public guardianship/conservatorship program must utilize a wide array of community services in order to respond to the varied needs of individual clients. Provision of competent social services for the protected person is a crucial element in serving the client.

\section{AREA AGENCY ON AGING}

The growth and development of the public guardianship and conservatorship program in Multnomah County since 1972 has parallelled the expansion of services to the elderly. The Area Agency on Aging (AAA) now provides services to persons over age 60 through 14 contracts with public and private agencies. Eight neighborhood-based agencies provide services such as outreach, organized social contact such as friendly visiting and telephone reassurance, information and referral, and assistance in utilizing available services including escort services. County-wide services include nutrition in the form of low-cost meals, employment possibilities for the elderly, homemaker and protective services. These services reach many of the estimated 
97,498 persons over age 60 who, according to 1970 census data, reside in Multnomah County.

AAA contracts with Metropolitan Family Service for protective services for the most vulnerable elderly. However, referrals to protective services come from senior centers, police departments, hospitals, community nurses, fire departments and the court system. Protective services at Metropolitan Family Service are funded by United Way as well as by AAA.

\section{AREA HOSPITALS}

Another major source of referrals has been the areawide hospitals. Aside from the Oregon Medical School having a social work department since 1930, it was not until 1966 that Kaiser Hospital and, in 1968, that Providence Medical Center hired social workers. Good Samaritan Hospital hired a social worker the following year, and Emanuel Hospital followed the trend in 1971. Presently all area hospitals have social work departments. Because many impaired persons, particularly the elderly, are spotted in the hospital setting, the hospital social worker, in concert with the physician, is often in an excellent position to make a determination of need for legal intervention. Because of the structure of the hospital social service setting, ongoing provision of needed services is not possible. 
ADULT AND FAMILY SERVICE DIVISION

Adult and Family Services (formerly Public Welfare Division) by nature of the categorical linkage requirements for services rendered are serving many persons with some impairment, often to the degree of incapacity. When such a person is no longer eligible for financial planning, usually because of increased financial benefits, a referral may be made for public conservatorship. Adult and Family Services usually continues to offer needed social services to the same individual.

The following table provides a picture of the local referring agencies and groups, as well as those who provide ongoing services when legal intervention has been established.

\section{TABLE X}

INITIAL REFERRAL AND PRIMARY SERVICE-PROVIDING AGENCIES, BY NUMBER

\begin{tabular}{lrlr}
\hline Referring Agency & $\#$ & $\begin{array}{l}\text { Primary Service- } \\
\text { Providing Agency }\end{array}$ & - \\
\cline { 2 - 4 } Metropolitan Family Srvc. & 29 & Metropolitan Family Srvc. & 42 \\
Hospitals & 24 & AFSD/CSD & 31 \\
AFSD/CSD & 17 & None & 7 \\
Families/Private G/C & 7 & Assn. Retarded Citizens & 6 \\
Senior Centers & 7 & Veterans Administration & 3 \\
Assn. Retarded Citizens & 3 & Mult. Co. Mental Health & 2 \\
VA Outpatient Clinic & 3 & Senior Centers & 2 \\
Public Health & 2 & Family members & 2 \\
Visiting Nurse Assn. & 2 & Nursing Home & 1 \\
Attorney & 1 & Adult Foster Home & 1 \\
Nursing Home & 1 & Blind Commission & 1 \\
Adult Foster Home & 1 & & TOTAL: \\
Railroad Retirement Board & 1 & & 98 \\
& TOTAL: 98 & & \\
\hline
\end{tabular}




\section{METROPOLITAN FAMILY SERVICE}

In view of the strong working relationship between the public guardian/conservator program and Geriatric Services Division, it seems appropriate to explore the elements of interaction and discuss how two specialized services collaborate to serve persons who are most often in the direst of circumstances and are referred after others in the community have tried and given up or have been unable to follow through with needed services.

The caseload of elderly persons who receive protective services from Geriatric Services Division consists of about 150 cases, some of whom are couples. Of these, about 25 percent have private conservators with banks, trust institutions, friends, relatives or court-appointed individuals. About 35 percent have either public guardianship or conservatorship appointments or combined appointments. 33 Aged persons in need of protective services have several distinguishing features. Their behavior is harmful to themselves and/or others, they may live in hazardous or unsafe conditions, they may be neglected or exploited, or be unable mentally or physically to act in their own behalf and carry out the activities of daily living. Because of losses suffered, physical and mental, they may have become isolated, frightened and withdrawn. They are often suspicious and resist any offers of help. The need for medical 
care may be ignored for years, often to the point of crisis. They usually have outlived any family or neighborhood connections and may, in a desperate need for human contact, display impaired judgment by reaching out to any stranger and thereby may be vulnerable to exploitation.

Pets may become a substitute for human contact and assume unusual importance in providing comfort and a reason for living (one elderly person had 27 cats and dogs). In most instances, the persons described are non-voluntary clients. They seldom, if ever, seek services and, when approached with help, are fearful, threatened and resistant.

\section{THE ROLE OF PROTECTIVE SERVICE}

The role of the protective service social worker is especially demanding. Knowledge of the aging process as well as good understanding of human behavior--normal as well as pathological--is essential in order to intervene effectively with an elderly person in need of protective services. The worker's own attitude toward older people, illness, incapacity and death will be reflected in the approach developed by the worker. It is important to come to terms with these feelings and be comfortable with them.

Special skills, based on knowledge, understanding and use of self are required for intervention with persons who are involuntary clients and severely limited in their ability to respond. This includes recognizing the elderly person's 
inability to ask for needed help and finding ways to reduce the fear, isolation and mistrust. The worker has to gain access, maintain contact, determine needs and assist an uninterested, unmotivated person to accept needed services that are offered and mobilized.

Developing a relationship of trust and mutual respect is a prerequisite to helping the elderly person assess what he can and cannot do. This process takes time and understanding of the person as a human being in the context of his total situation. Every effort is made to support and maximize whatever capacity the individual has for making decisions in his own behalf. All options are presented. The assistance of "interested others" is enlisted as we11. Because they may have had difficult experiences with the elderly person and perhaps have given up, involving others again in the effort of giving help may require considerable discussion to clarify misconceptions or misunderstandings about the client's behavior. Essentially, the protective services worker attempts to understand the individual's unique mental and physical functioning, while attempting to stabilize the situation and effect some balance in the relationship between the individual and his environment. See Appendix A for expanded definition of protective services for older people.

When a client is willing to accept services which will protect him from harmful or dangerous circumstances, he is 
a voluntary client. Many elderly persons are able, with help, to plan realistically for themselves. An example is a blind person who is mentally alert. This planning often includes legal intervention as well. The point at which the risks and dangers are too great to tolerate, however, requires the worker to make the judgment to request legal intervention. Decision making in offering protective services is a heavy burden. Involvement of the client in making his own decisions as much as possible is critical in preserving individual integrity and spirit. The guiding philosophy for the worker is to employ the least amount of legal intervention necessary for a person's protection and to utilize the least restrictive alternatives. This philosophy, however, does not hold without the concomitant factor of skilled social work practice.

Edna Wasser, in her article "Protective Practice in Serving the Mentally Impaired Aged," describes the particularly difficult issue of the involuntary client:

The securing of guardianship in relation to an involuntary client, however, in no way lessens the difficulty of enforcing legal decisions even though these have been deemed essential for the client's survival. THERE IS NO MAGIC IN GUARDIANSHIP (emphasis added). How does one proceed to get a completely negativistic, ill, frightened, and helpless person to leave a foul setting that he prefers, although he cannot be cared for adequately there? After all, if the purpose of moving a recalcitrant human being to another setting--even a hospital--is to help him survive, the worker must be acutely aware that the client not be destroyed in the process. 34 


\section{COLLABORATION BETWEEN PUBLIC GUARDIAN-CONSERVATOR} AND PROTECTIVE SERVICES

Referral is by letter to the public guardian/conservator program, outlining in detail significant identifying information, reason for referral, the current situation, who significant others might be, medical, financial, and legal information. The request specifically indicates whether guardianship, conservatorship, or both are needed. See Appendix A for sample of letter guide. The referring agency assumes responsibility to see that available medical and/or psychiatric reports are sent as well. This ensures that the process will not be postponed while such reports are prepared and mailed. All reports are filed with the petition requesting legal intervention.

The next step, ideally, is to arrange a meeting with the incapacitated person by the social worker and the public guardian/conservator. At this time, questions, concerns, and fears again are dealt with as well as the beginning of agreements between all concerned about future plans. When legal intervention is granted by the Probate Court, close collaboration and consultation on behalf of the mutual client begins to occur. On a bi-monthly basis, individual case planning takes place at a regularly scheduled conference between the public guardian/conservator and Geriatric Services Division workers. 
Contact continues as required, by frequent telephone communication. Coordination of needed services for the individual client is given priority. In Multnomah County, the blending of the much-discussed interdisciplinary services, medical-legal-social work disciplines, on behalf of the incapacitated person have been thoughtfully and carefully developed.

The social worker assumes responsibility for maintaining continued close contact with the client, and is a key element in seeing that needed services are provided. The social worker can contribute special understanding of the environmental stresses, social and emotional needs of the incapacitated person.

The physician contributes understanding of the person's physical status and potentialities. He can provide needed ongoing medical supervision.

The guardian can provide a constructive, stabilizing influence by assuming needed responsibilities for major decisions on the client's behalf, such as where to live or be cared for.

The conservator may bring financial assets under control and establish mechanisms by which the client can benefit from his own resources.

An example of such cooperation occurs whenever such incapacitated persons are admitted to Woodland Park Mental Health Center. By arrangement the three disciplines pool 
their expertise in an effort to totally evaluate the individual's wishes and needs. When possible, the individual is returned home with appropriate supports, such as medication supervision, meals-on-wheels, homemaker service and financial management. If indicated, a different living arrangement may be necessary. It may be temporary, such as nursing home placement to regain needed strength for independent living. All action taken is directed toward supporting and maximizing whatever capacity for independence the person has.

This actual case vignette is an example of successful collaboration between the public guardian/conservator and protective service:

Mr. G. was referred by police after a cab driver found him malnourished, weak, and infested with lice.

His house was a filthy health and fire hazard. Utilities were shut off due to non-payment of bills. Taxes were delinquent and the court had attached his safety deposit box for non-payment of a hospital bill. He spent most of his $\$ 365$ Civil Service pension on old Hermitage.

Mr. G. had been a cost accountant in the service and was eligible for Veterans Hospital care. Because they didn't consider his physical condition severe enough he was on their lowest priority while his alcoholism was too severe to allow him to accept treatment voluntarily. Therefore V.A. services were denied.

Arrangements were made for medical/psychiatric evaluation at a private hospital. He was found to be depressed, brain damaged due to arteriosclerosis and alcoholism, and unable to control or regulate essential details of his life.

He needed: financial protection, home repair and clean up, adequate nutrition, personal care and hygiene, and limits on his drinking. 
Appointment of both public guardian and conservator (without objection by the client, interesting1y) served to implant securely the "heavy artillery" needed to blast away at the above-described problems. The conservator's first order of priority lay with the shambles of $\mathrm{Mr}$. G's financial situation (settling up with the finance company that had attached his safety deposit box containing most of his assets, getting I.R.S. off his back, paying up four years of delinquent property taxes, etc.).

This was a separate function from social services, which were concerned chiefly with initiating heavy house cleaning, homemaker and personal care services, and replacement and/or repair of most appliances, ranging from hot water heater all the way down to light bulbs. Perhaps the most important social service innovations (made possible also by the legal intervention) were the improvements in diet through agency volunteer grocery shopping for him, negotiating a "voucher system" with his neighborhood luncheonette and controlling his spending (i.e., booze) money through a weekly allowance administered by his closest neighbor.

The interaction of these services were characterized by mutual planning, initiation of needed services, continual collaboration and establishment of a workable monitoring system. Several community agencies had attempted to provide help in the past without success. It was not until the establishment of public guardianship and conservatorship in cooperation with protective social services that the key to working with $\mathrm{Mr}$. G was found. Thus, the presence of both programs has been the major element to allowing $\mathrm{Mr}$. G to live comfortably in his own home, and thereby refuting medical-psychiatric prognosis of brain damage so severe as to require institutional care.

This kind of planning can insure that the incapacitated person is provided the best available service with every effort directed to maintaining him in the community. We forget that people, particularly the elderly, have had a life-time of coping and adapting. With appropriate help, in familiar surroundings, they can often gain mastery over their circumstances. Although institutional care is, at 
times, necessary for certain individuals, overall the cost in human values as well as economics far exceeds the benefit. Community-based services which are capable of responding to real needs and are sensitively delivered are to be preferred. 
CHAPTER VII

CONCLUSIONS

This study was an effort to describe the development and operation of a program established in 1972 .

This study is not complete. A thorough examination of the law and its implications was not attempted. Analysis of data was limited to this one program. No attempt was made to generalize or draw conclusions to similar populations or programs in other states. The time element as well as the expertise required to provide useful comparisons were factors. This is the first written attempt to pull together the elements of community interaction that have resulted in the establishment and operation of the first public guardian and conservator's program in Oregon.

\section{STRENGTHS OF THE PROGRAM}

The program has served approximately 500 persons declared to be in need of legal intervention by the Probate Court. Services have been provided despite a small budget, minimum staff, inadequate space and no organized community support or advisory group to assist the program. The program began and has continued with a low profile in the community. 
Services provided are mandated by Oregon statute. Aside from administering the law, the response to client needs indicates an understanding and acceptance of individual concerns. A significant amount of time is spent in the intake and screening process by the public guardian. Consultation enables the public to sometimes avoid or minimize the necessity for guardianship and conservatorship. The public guardian and conservator also serves as a model of providing standards of service to other people appointed as private guardian or conservator.

A program priority has been the establishment and maintenance of good working relationships with various governmental bodies, public and private agencies and institutions to assure the most effective program for each person. Because of a personal commitment to the program, the public guardian puts in long hours in the attempt to respond to all legitimate needs of the clients.

The program has served persons for whom other resources have proven ineffective or unavailable. Legal intervention, in cooperation with social services, has provided the structure required to maintain individuals at a functioning level in the community. Although it is difficult to demonstrate precisely, the real result of the program is that the incapacitated person, elderly or young, is afforded a choice to remain in the community rather than being forced into traditional institutionalization. As a result, the 
dignity in making one's own choice is supported and made possible.

Program effectiveness might be measured by the outcome element of meeting an identified community need by offering a specific service for a specific client. The program has no skills or resources at this time to develop outcome criteria or support formal evaluation mechanisms.

\section{LIMITATIONS OF THE PROGRAM}

When the program was established by the County Commissioners in 1972, there were no existing programs to provide guidelines. Because it was necessary to limit spending, essentially a token service was sanctioned. A county employee from the Division of Records without direct experience in working with incapacitated persons was appointed as the first public guardian. Early development of the program suffered from a lack of development of relationships with agencies to provide services to clients, inadequate program procedures and failure to establish and maintain adequate records. As a result, the continuum of care so important to successful working with incapacitated persons was missing.

Today the program is still plagued by some problems, but not the same as the early years. Funding is a major concern and underlies the need for the program to maintain a low profile in the community. The minimum staff operates 
at the maximum level due to a high caseload and resulting demands. A small budget with large demands leads to severe time constraints. While services directly affecting the clients such as agency relationships and establishment of adequate records are given priority, there are gaps in the program that need attention. These include:

1) Preparation of written program procedures, formulated and adopted to promote efficiency. Such procedures would be essential to other programs in undertaking similar services.

2) Time to develop community relationships to the fullest extent possible in order to assure proper referrals and reduce efforts expended on an individual basis to educate and train others when and how to utilize the service.

3) Development of a community advisory group to support the program and lobby on behalf of the clients of the service for continuation and appropriate expansion of the program.

4) Addition of staff to directly assist the public guardian/conservator. The growing function of screening and consultation with the community requires considerable time.

5) Adequate time to plan for all aspects of the program and its continuing development. 


\section{PLANNING FOR THE FUTURE}

\section{Multnomah County}

Expansion. Expansion of the present program has been gradual. The demands for services are growing. According to the survey of the active December 1977 caseload, 71 percent of the total population served was age 60 and over. Older Oregonians Universe, compiled by Oregon's State Program on Aging, indicates the decade between 1970 and 1980 will show a 24 percent increase in the age-60-and-over population in Oregon. 35 In 1970, Multnomah County had 97,524 over age 60. In 1978 the figure has risen to 112,686. The projection for 1980 is $116,020.36$

A formula evolved from the 1967 Portland Workshop on Protective Services for Older People and was used to estimate 500 to 600 county residents over age 60 to be in need of legal protection. It was Margaret Blenkner, Director of the Benjamin Rose Institute in Ohio, who--based on her experience with persons in need of protection--estimated that 7 to 8 percent of the population was in need of protective service. Tri-County Community Council then estimated 10 percent of this group may require actual legal intervention in the form of guardian or conservator services. In the absence of a better method to estimate, and using the same formula, Multnomah County in 1978 would have 784 elderly in need. By 1980 the number will rise to 812 . Some do 
not come to the attention of the public guardian. Many are already known to private guardians or conservators such as relatives, friends, lawyers or banks. At the present there are, in fact, approximately 2,700 private guardians and conservators appointed by the court in Multnomah County. Estimated figures of need would appear to be conservative. A significant factor is the inability to judge the extent of the need for the public program at any one time. While some do come to the public program for help, there are reasons that many, particularly the elderly, do not make use of the service. The literature discusses two main reasons. Older persons with severe incapacity may continue without assistance because of the invisibility that comes with social isolation. The second reason is simply the ability on the part of the older person to meet one's own minimum physical needs and thereby attract little attention. 37

Services to the elderly and the incapacitated have, until recently, been given low priority in our society. They are, for the most part, unable to speak on their own behalf. Efforts to make need more visible and secure adequate services is to be encouraged.

Organization. A locally based program is essential for a sensitive response to both clients and available resources. Additional staff to directly assist the public guardian-conservator is necessary due to the continuing number of demands. A breakdown in tasks might prove 
helpful as well. Intake, screening and initial establishment of plans for the client could be a full-time function and is a high demand time in the life of a case. Managing ongoing cases and effecting appropriate terminations also requires much time and special but different expertise. Inter-organizational. The need to develop and maintain relationships with referring agencies as well as those providing ongoing services is essential to good program development. Because so much of the caseload is elderly and their overwhelming need is for personal care, strong linkages with outside resources must continue to be forged. Cost. Adequate funding underlies the ability of the service to function. Because of the wide range of persons served, other programs might contract for services or be persuaded to support the program. A County funded program requires renewed commitments each fiscal year. State-Wide Program

Expansion. While long-term medical and nursing care will be necessary for many persons, the option of choice to remain in the community is increasing as supportive services increase. The options for the legally incapacitated person must increase as well. The public guardian-conservator program provides such an option.

Expansion of the service into a state-wide program could provide the opportunity for many more persons to live in the community where they can, with appropriate 
assistance, continue to be independent, more mobile and near familiar people. The objective should be to permit people to remain in their own homes as long as they can or want to. When this is no longer possible, need and preference should determine the next plan. With the combination of public guardian-conservator and specialized social services, a continuum of care for the legally incapacitated person can be provided. While institutionalization as a long-term method of care is generally viewed as an option to be avoided, it must be available to those for whom more independent living is not possible.

It is not possible to accurately estimate Oregon's unmet need in terms of incapacitated persons that may require legal intervention. The one population we can estimated, however, with some degree of accuracy is the elderly. Older Oregonians Universe indicates Oregon's 1978 population of over age 60 is 277,386 persons. By 1980 the figure will reach $289,940.38$ According to a January 18 , 1973 Oregonian article, current population trends indicate that one out of every six Americans alive in the year 2030 will be age 65 or older. Using a formula devised earlier, the state-wide estimate for elderly incapacitated persons in need of legal intervention in Oregon would be 1,939 in 1978 and 2,030 in 1980.

Because much of Oregon is rural with large concentrations of elderly in the urban areas, some adaptation in the 
possible expansion of the program would need to be considered. Rather than expanding on a county-by-county basis, as now called for by legislation, it may be more reasonable to plan in terms of regional programs. A statewide program would facilitate transfers from area to area and accommodate the desire for mobility. Because Multnomah County has established and sustained a successful program, the experiences gained could be utilized by the other areas. A phase-in plan would appear to have merit.

Organization. Expansion of the program would require an examination of possible options for organization. The question revolves around county vs. regional and state systems. The current county plan ensures the ability of the public guardian-conservator to be sensitive to the needs of clients, flexible about program planning and service delivery as well as knowledgable about local resources. For an expansion of the county plan, limitations have to do with a reduced number of potential clients in rural areas making it impossible to justify a separate program in each county. Each county might develop a unique program making uniformity and accountability more difficult to achieve. Funding as it is presently conceived is also an inhibiting factor in expansion, as many counties are unable to assume the cost.

An alternative might be to make the public guardianconservator program a division of a state agency. Funding 
concerns would be reduced and availability and accessibility could be increased. The independence of the program as well as the ability to accept clients from all sources might, however, be sacrificed by the structure.

Another alternative would be to create an independent office directly under the State Department of Human Resources. In accordance with the factors of demand and population density, the program could be established on a regional basis. This centralized administration would ensure greater uniformity in standards, comprehensive coverage and greater integration of state and local efforts. A state coordinator could establish procedures, select and train personnel and direct program activities. Al1 personnel would be processed through civil service with certain educational requirements to be met. Records and data could be precise and consistent. This approach would tend to equalize what is now an unequal service.

Inter-organizational. In whatever approach might be utilized in program expansion, the linkages necessary for quality service must be considered. In this way a continuum of care for the legally incapacitated person can be assured. Because the provision of protective services is utilized at such a high rate in Multnomah County, expansion of this specialized service requires attention as well. At the present time, Multnomah County, just as with the public guardian-conservator program, is the only Oregon county 
where special protective services are provided.

Possible options in the expansion of the program might be for a protective service social worker to be made available to each new program through the cooperation and funding of the court and/or Adult and Family Services Division. Another option is for a protective service social worker to be hired in each area or region for the purpose of teaching and training referral sources. Or a social worker could, from the central office, travel the state, contacting agencies, AAAs, community nurses and others for the purpose of explaining and instructing how to utilize the program. The factors of accessibility and proper utilization of the service cannot be ignored.

The actual provision of ongoing protective services is just as essential. The most stable funding for protective services would be directly through the state under Title XX of the Social Security Act. It is possible that if the state assumed responsibility for funding this service under Title XX, it might choose to administer the service directly. Provisions could, however, also be made for contracting as well. Though Adult and Family Services Division has legislative authorization to provide protective services, they have devoted very few resources to this area. Exploration of the development and the delivery of state-wide adult protective services needs attention. 
Cost. Funding may have to come from a variety of sources before expansion is possible. Existing programs representing linkages such as the State Program on Aging or the courts might make funds available. The State Department of Mental Health may view the program as important to fund as a constructive alternative to institutionalization. Perhaps the legislature could authorize funds to be matched by local resources. Space and transportation costs might be assumed by local areas.

It is clear there is a growing need for services that will provide structure and support for severely incapacitated persons who wish to remain in the community. Not only is there a continuing state-wide trend toward establishment of alternatives to institutionalization, but there is a growing number of persons, particularly the elderly, who in the absence of family members need special services in order to cope with an increasingly complex society.

Present1y the resources developed to respond to the ne:ds are inadequate. The organizational forms that could be taken by the public guardian and conservator's program are multiple. In terms of expansion it is clear that new legislation is required. A major conclusion is that the time has arrived for the establishment of a task force charged with the responsibility to determine how expansion wolid best be structured. Concerned people will have to 
take action, the recipients are unable to speak on their own behalf. Public will as much as community need will influence the development and expansion of this service. 
FOOTNOTE REFERENCES

$1_{\text {Beverly Diamond, Introduction, Seminar on Protective }}$ Services for Older People, NOCA (March 1963), p. 13.

${ }^{2}$ Early guardianship law refers to protection of both the person and the estate. In 1973 Oregon law separated guardianship into protection of the individual and conservatorship into protection of the estate.

${ }^{3}$ Iowa Law Review, Vo1, 45, No. 2 (Winter 1960), p. 337.

4 George J. Alexander and Travis H. D. Lewin, The Aged and the Need for Surrogate Management (1972), p. 2 .

5 Ibid., p. 8 .

6Ibid., p. 17

7 Ibid., p. 7.

${ }^{8}$ The Law and the Impaired 01der Person: Protection or Punishment? The National Council on Aging, edited by Gert trude H. Hal1 (March 1966), p. 16.

${ }^{9} \mathrm{Alexander}$ and Lewin, p. 19.

10Ibid., p. 25.

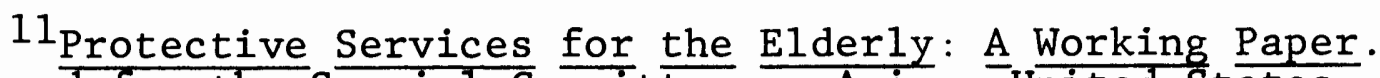
Prepared for the special Committee on Aging, United States Senate (July 1977), p. 32 .

12 Yale Law Review, Vol. 73, No. 4 (March 1964), p. 691.

${ }^{13}$ A Crucial Issue in Social Work Practice, Protective Services for 01der People, Proceedings of two sessions from the National Conference on Social Welfare (May 1965), p. 34.

${ }^{14}$ Hasseltine Byrd Taylor, Law of Guardian and Ward, Social Service Monographs, No. 35 , University of Chicago (1935), p. 9.

15 Ibid., p. 9. 
16 Ibid., p. 10.

17 Ibid., p. 11.

18 Ibid., p. 14.

${ }^{19}$ Ibid., p. 15.

${ }^{20}$ Ibid., p. 16.

21 Protective Services for the Elderly, pp. 28-29.

22 Taylor, p. 18.

23 Protective Services for the E1derly, p. 29.

24 Ibid., p. 30.

25Virginia Lehmann and Geneva Mathiasen, Guardianship and Protective Services for older People, NCOA press (1963), p. $2 \overline{3}$.

26 Taylor, p. 62 .

27 The Law and the Impaired 01der Person: Protection or Punishment? Preface, Hyman Smollar, pp.i-ii.

28 Ibid., p. 51.

${ }^{29}$ Protective Services for the Elderly, pp. 41-42.

${ }^{30}$ Excerpts from: Seminar on Protective Services for older People: Proceedings of a seminar held at Arden House, Harriman, New York, March 10-15, 1963. Definition used by sub-committee on protective services and by 1967 Workshop on Protective Services for 01der Adults held in Portland, Oregon.

${ }^{31}$ Sheila B. Kammerman and Alfred J. Kahn, Social Services in the United States, Temple University Press, Philadelphia (1976), p. 319.

32 Ibid., p. 313.

33Lydia J. Strnad, Director, Geriatric Services Division, Metropolitan Family Service, Portland, Oregon, personal interview held March 15, 1978. 
${ }^{34}$ Edna Wasser, Social Casework, "Protective Practice in Serving the Mentally Impaired Aged," Vol. 52, No. 8 (October 1971), p. 515.

3501der Oregonians Universe, Oregon State Program on Aging (September 1974), p. 19.

36 Ibid., pp. 20-21.

37 Workshop on Protective Services for o1der Adults, co-sponsored by Friendly House, Inc., and Tri-County Community Council Committee on Aging, Portland, Oregon (November 2-4, 1967), p. 2 .

${ }^{38}$ older Oregonians Universe, p. 23. 


\section{BIBLIOGRAPHY}

A Crucial Issue in Social Work Practice, The National Council on Aging, 1966.

Alexander, George J. and Travis H.D. Lewin, The Aged and the Need for Surrogate Management, Syracuse, N.Y.: Syracuse University, 1972.

American Jurisprudence, Second Edition, Vo1. 39. The Lawyers Co-Operative Publishing Co., Rochester, N.Y., 1968.

Annual Report to the President - 1976, Federal Council on the Aging, Washington, D.C.

Benjamin Rose Institute, Cleveland, Ohio, Vol. I. Final

Report: Protective Services for Older People. Margaret Blenkner, Martin B1oom, Margaret Niels en, Ruth Weber, 1974 .

Corpus Juris Secundum. Vo1. 39. St. Paul, Minn. West Publishing Co., 1976.

Ha11, Gertrude H. and Geneva Mathiasen, Guide to Development of Protective Services for 01der People, Charles C. Thomas, Publisher, Springfield, IIlinois, 1973.

Hobbs, Lola, Public Welfare, Summer 1976 "Adult Protective Services: A New Program Approach."

Iowa Law Review, Vol. 45, No. 2, Winter 1960, "Symposium: Guardianships."

Kamerman, Sheila B. and Alfred J. Kahn, Social Services in the United States, Temple University Press, Philadelphia, 1976.

Lehmann, Virginia and Geneva Mathiasen, Guardianship and Protective Services for $\underline{\text { Older }}$ People. New York: Fort Orange Press, 1963.

National Council on the Aging, The Law and the Impaired Older Person: Protection or Punishment? Edited by Gertrude H. Ha11, New York, 1966. 
Protective Services for the Elderly: A Working Paper, prepared for the special Commit tee on Aging, United States Senate, July 1977.

Protective Services Project for 01der Adults, U.S. Dept. of Health, Education and Welfare, DHEW Publication No. (SRS) 72-23008. 1971 .

Taylor, Hasseltine Byrd, Law of Guardian and Ward, The University of Chicago press, Chicago, Illinois, 1935.

Wasser, Edna, Social Casework, 42, Nos. 5/6, May/June 1961, "Responsibility, Self-Determination and Authority in Casework Protection of Older Persons."

Workshop on Protective Services for Older Adults, co-sponsored by Friendly House, Inc. and Tri-County Community Council Committee on Aging, Portland, Oregon, Nov. 2-4, 1967.

Yale Law Journal, 73, No. 4, March 1964, "The Disguised Oppression of Involuntary Guardianship: Have the Elderly Freedom to Spend?" p. 676-92. 
APPENDIX A 
BEFORE THE BOARD OF COULTY COMNISSIONIRS FOR

MULTNONOAH COUNTY, OREGON

In the Matter of the sistablishment of ,

the office of PUBLIC GUARDIAls and the

Appoiltment of a public cuardian vitisin the Department of Records and Elections )

DRDER

The above-entitled matter is before the Board pursuant to the provisions of ORS 126.905 - ORS 126.965 to consider the establishment of the Office of Pubiic Guardian within Multnomah county and the appointment of a public guardian to carry out the functions of such office; and

It appearing to the Board that there exists a need within Multnomah County for a guarcian for persons who do not have relatives or friends willing to serve as a guardian and capable of assuming the cuties of guardianship; and

- It further appearing to the soard that it would be appropriate at this tine to establish such an office and make the appointment of a public guardian in the best interests of Multnonah County; and the Board being.fully advised in the prenises, it is therefore

ORDERED that the office of Public Guardian be and it is hereby established within the Dejurtment of Records and Elections of Multnomah County, Oregon, effective January 1, 1572, in accordance with the authority vested in the Board of county commissioners by the provisions of ORS 126.905 - ORS 126.965; and it is

FURTHER ORDERED that a suitable person within the Departiment of Records and Elections be appointed Public Guardian to exercise the rights, powers and authority vested in a public guardian under ORS 126.905 - ORS 126.965; and it is

FURTHER ORDERED that said Public Guardian so appointed shall file an official bond in an amount designated by the probate Court for the joint benefit of the several guardianship estates in which he may be appointed by the court as a guardian.

December 30,1971

APPROVED AS TO FORM:

DESMOND D. CONNALL

Distrige Attorney for

Multnorlah County, Oregon

By
BOARD OF COUNTY CONMISSIONERS MULTNOILAH COUNTY, OREGON 
December 1, 1977

Mr. Paul E. Nizdil

Public Guardian \& Conservator

Room 220 County Courthouse

Portland, Oregon 97204

Dear Paul:

As you know, I am interested in doing a description of the Multnomah County Public Guardian and

Conservator's Program. In order to make this project as useful as possible, I would like to have access to the program's case records. Data gathered will be used to describe characteristics of the population served by the program. All information pertaining to individual clients will be kept confidential.

I will appreciate the cooperation of you and your staff.

Sincerely, 
ORS $126.905-126.965$

\section{PUBLIC GUARDIANS AND CONSERVATORS}

126.905 Office of public guardian and conservator; expenses; termination. The county court or board of county commissioners of any county:

(1) After making a determination that there exists a need within the county for a guardian or conservator for persons who do not have relatives or friends willing to serve as a guardian or conservator and capable of assuming the duties of guardianship or conservatorship, may create within the county the office of public guardian and conservator and such subordinate positions as may be necessary to operate effectively the office of public guardian and conservator within the county.

(2) May expend county funds for the purpose of operating the office of public guardian and conservator.

(3) After establishment of the office of public guardian and conservator within a county, upon the finding that the county does not need the service of a public guardian and conservator, may terminate the office. (1969 c.627 s.1; 1973 c.823 s.116)

\subsection{Effect of vacancy in office of public}

guardian. The person appointed to the office of public guardian shall serve in the office at the pleasure of the appointing authority. If the person holding the office of public guardian in a county is removed from office, dies, becomes incapacitated or resigns, his removal, death, incapacity or resignation shall operate to remove such public guardian as guardian of all estates then under his guardianship.

$$
\text { (1969 c.627 s.2) }
$$

126.925 Powers and duties of public guardian and conservator. (1) The public guardian and conservator may serve as the guardian or conservator, or both, of any person of whom the court having probate jurisdiction in the county may have jurisdiction. The public guardian and conservator may serve as guardian or conservator upon the petition of any person or upon his own petition. 
(2) When appointed as guardian or conservator by the court having probate jurisdiction, the public guardian and conservator shall serve as provided in ORS 126.003 to 126.413 , except as specifically stated to the contrary in ORS 126.905 to 126.965 .

(3) The public guardian and conservator in his discretion may employ private attorneys if the fees for the attorneys can be defrayed out of funds of the guardianship or conservatorship estate. (1969 c.627 ss. 3,6; 1973 c.823 s.117)

126.935 Bond; exoneration of surety. (1) Before entering into office as public guardian and conservator, the person appointed to the office shall file an official bond in such amount as may be fixed from time to time by the board of county commissioners or the court having probate jurisdiction, which bond shall inure to the joint benefit of the several guardianship or conservatorship estates in which he is acting as guardian or conservator and the county. The public guardian and conservator shall not be required to file bonds in individual estates.

(2) Upon removal of the public guardian and conservator in accordance with the provisions of ORS 126.915, the surety on the public guardian and conservator bond shall be exonerated upon order to that effect of the court having probate jurisdiction in the county. (1969 c.627 s.4; 1973 c.823 s.118)

126.945 Deposit of funds. All funds coming into the custody of the public guardian and conservator shall be deposited in the county treasury and disbursed by proper warrant, or shall be deposited in one or more banks or invested in one or more insured savings and loan associations authorized to do business within the county, or as provided by subsection (5) of ORS 126.313. (1969 c.627 s.5; 1973 c.823 s.119)

126.955. Reimbursement of public guardian and conservator's expenses from estate of ward or protected person. The public guardian and conservator shall have a claim against the ward's or protected person's estate for his reasonable expenses incurred in the execution of the guardianship or conservatorship and such compensation for his services and those of his attorney as the court having probate jurisdiction in the county deems just and reasonable. If the public guardian and conservator is compensated by the county for his services, any reimbursement of expenses or compensation shall be paid to the county. (1969 c.627 s.7; 1973 c.823 s.120) 
126.965 Fees prohibited. No fee shall be charged or received by the county clerk for the filing of any petition asking for the appointment of the public guardian and conservator or for any official service performed by the county clerk in the course of the guardianship or conservatorship proceedings.

(1969 c.627 s.8; 1973 c.823 s.121) 
Protective Services for older People

A Definition

1. General Definition:

Protective service is the constellation of services utilized and coordinated by an agency or an individual to assist impaired elderly persons who manifest incapacity in their mental, emotional and physical functioning to such a degree that it does or will result in harm or hazard to themselves or others.

2. Distinguishing Features:

A person in need of protective services has one or more of the following characteristics:

1) Physical or mental limitations which render him unable to act in his own behalf, to manage money and/or carry on activities of daily living.

2) Behaves in a way that is harmful to himself or others.

3) Is mentally incompetent to the degree that legal measures are, or foreseeably will be necessary for his own or others protection, e.g., legal representative, guardianship, commitment.

4) Is living in unsafe or hazardous conditions.

5) Is neglected or exploited.

6) Is without anyone reliable, ready and willing or able to act in his pehalf, i.e. family member, relative, friend. 1

7) His problems are out of control.

3. Target Population:

People in need of protective services do not ask for help. but rather, are referred by concerned neighbors, friends. police, utility companies, Polution Authority, hospitals or any of the myriad of other community services or groups. They usually resist any offer of help, often out of fear that something will be done to or forced upon them. They often trust no one, cling tenaciously to their last stronghold (that which is familiar) despite filth, neglect and illness. They are reclusive, suspicious and may not have had medical care for years. They suffer from mental illness

If Protective Service Project for Older Adults, U.S. Dept, HEW, Wn. D.C., 1971 
and/or mental deterioration and nay also be physicaliy deteriorated or ill.

Examples:

1) An 80-year old who kept 17 starving cats in the kitchen, was reported by neighbors to the sanitation department and refused them entry. She also suffered from malnutrition and personal neglect. (Everybody else suffered from the odor.)

2) The 70 year old lady with a severe heart condition who didn't have money for food or rent because she couldn't remember to collect rent from some rooms she sub-rented in her leased flat. She drove her car in the middle of the street "because that was safest", and ran up phenomenal bills for gas at service stations for trips as she didn't realize that credit cards aren' $t$ cash and bills need to be paid.

3) The elderly lady who threw dog excrement at her neighbor's window in retaliation for his sending electronic rays through her house, through her and her dog and causing her and the dog a painful illness.

4) The 65 year old who moved from place to place, leaving her possessions behind, not remembering where she lived and accusing people of stealing her belongings. She purchased food and threw it in the garbage can. Not only was she malnourished, but also suffered from premature senility.

5) The physically ill and incapacitated lady who sat in her easy chair day and night and was unable physically to manage even the minimal necessities to sustain life (nutrition, toileting, selfcare, etc).

4. Goals:

The aim of protective service is to help these individuals in whatever way necessary to bring their situation under control for their safety and well-being: to reduce stress and improve their functioning by mobilizing and enabling them to use those services that will help them function at the highest level of competence of which they are capable and to do or get done for them those essentials they cannot do for themselves. Prevention is inherent in the goals of treatment in the respect that it arrests or prevents continuing deterioration. 
While legal intervention (guardianship and/or commitment to a mental institution) and professional. authority are sometimes necessary, this is not generally the method that is most helpful to the majority of people in need of protection. It can be a valuable and necessary. resource. when needed and if it is used appropriately and with discrimination. similarly, neither is placement in a nursing home or other protected environment always needed.

Nationally, social casework has been considered the method of choice in protectice service delivery. But the complexity of problems necessitates a multi-disciplinary and an interdisciplinary approach. A wide variety of community resources are needed, singly or in differing combinations and at different times as each situation demands. The fact that these resources exist, are available and offered to the person in need of protection does not preclude that he can or will use them, (medical care, home-delivered meals, clean-up service, home nursing, home health care, homemaker service, fiduciary and legal services, transportation and shopping services, supervised living arrangements). The fact remains that it is the impaired older person who is the center of focus in the problems and he needs to be approached and worked with in direct personal contact. The key in this helping process is the social worker who gains entry. develops a trusting relationship, ferrets out his strengths and works with the older person, involving him in every step along the way to bring about a change for the better. Nor is this the end. Because of the human condition, things do not remain static. And while older people "have their full share of acute illness and social crisis, it is not acuteness and crisis that characterizes their patterns of need but chronicity and increasing dependency. Failure to face up to this is at the heart of many of our failures in planning for older people." 2/

It is the social worker's ability to integrate information about the impaired older person with his knowledge of human behavior and casework skills that brings about a change for the better. Protective casework practice in its highest form is a blending of human compassion with knowledge and skill at its most effective level.

2/ Blenkner, M., "Protective Services: Needs, Professional and Community Responsibility". Protective Service for Older Adults Workshop. Edited by M. Hughes, Portland,Oregon: Friendly House, Inc. 1967 
The following is intended to be used as a guide for the social worker and not as a check list form since each client is unique and needs to be treated individually.

Re: Full name and middle initial

Address

Telephone number

Birthdate

Narital status

Medicare number (including letter)

Other health insurance and policy \#

Religious preference

If a couple is being referred, give data for each.

I. Reason for Referrel:

Referral for What: Guardianship, conservatorship or both.

Why : Clear conoise statement

(Unable to manage finances and why.

Exploited or subject to exploitation and

by whom. Forgetful, confused, blind, etc. Needs medical attention and is refusing, needs protected living arrangements and refuses.)

II. Current S1tuation:

1. Source and circumstances of referral to welfare.

2. Worker's evaluation of total situation and functioning:

(succinct but specific, citing dangers.)

3. Client's functioning:

Niental

Physical

Flnancial

Social

Behavioral

Relationships

Attitudes

Self-care

Past exployment

III. Significant Others: (Also indicate which ones were contacted, interviewed and include signiflcant information.)

1. Relatives:

Name

Address

Telephone number

Relationship to client

Frequency and kind of contact and nature of help 
2. Neighbors - Friends - Others

For the above, rule out willingness and feasibility for any of these to serve in the capacity of guardian and/or conservator. Include client's wishes.

3. Other Agencies:

Name and telephone numbers of agency (s) and names of persons helping and in what way (8).

4. Key Person in Client's Life

IV. Medical:

1. Physician

Name

Address

Telephone number
Hospital

Name

Address

Telephone number

2. Current liedical problems, handicap.

3. Medical History including doctors, hospitalizations, etc., with names and dates.

4. Current Medical Report including statement of doctor's opinion relating to ability to manage own affairs.

5. Current Medical Report to be attached to letter of referral to public guardian.

7. Financial:

1. Income

Amount and source (s)

(If pension, state what lind or from where)

2. Assets

Real Property

Describe and give details

(that, where located and assessed value if known, are

taxes current? Property tax refund filed?)

Stocks, Bonds, Certificates

Cirie details

Bank Accounts

Savings and Checking - Account numbers, name (s) of bank, address and telephone number, location of bank books.

Safety Deposit Box

Name and address of bank, where 1o key to box. 


Insurance: Life $\quad$ Car 105

Funeral - Pre-arranged? Pre-pald? Name of funeral home. Plot - Name of cemetery, prepaid?

Name and address of Insurance Company

Name, address, telephone number of Insurance Agent

Is insurance paid up? Amount of premiums, due dates and date to which paid.

Status of Medicare reimbursements

$\begin{array}{ll}\text { Other Valuables: } & \text { Antiques } \\ & \text { Jewelry } \\ \text { Pets } & \text { describe }\end{array}$

Loans - Debts: Cire details

Cash on Hand: Give date, amount and Location

(If client is in hoopdtal, nursing home, etc.. are valuables locked in the institution's safe?)

VI. Legal:

VII. Other Details:

Does or did client have an attorney? Name, address and phone number. Will - where located and name of executor

1. Was plan for conservatorship and/or guardian discussed with client and other key persons (relatives primarily)? lhat were the responses?

2. Who will provide on-going social work services? What is social worker's plan (briefly) and altermatives?

3. What preferences or wishes has cllent expressed in eny areas?

VIII. Guardianship Oniy:

When the need and request is for guardian-of-person only, all the above information is needed except (possibly) the detailed financial information. However, It is necessary for the guardian to know the amount of assets and who is responsible for the handling the assets. The guardian does need to know that property is protected. The social worker should indicate who (name and address) is handling finances and in what capacity (conservator, power of attorney, trust officer, otc.) and that he has handled it capably and will continue doing so. If the social worker has questions or concerns about how finances are being handled, it is important to state the facts. This refers not only to income but also to financial assets, property and other possessions.

The social worker should project whether the guardian needs to put any attention to protection of property and essets. Example: A conservatorship may have been applied for and not in effect and possessions are being exploited.

State clearly what the guardianship is for. If temporary to meet a specific need, so indicate. (Example: Cuardianship is necessary to hospitalize client. Or, if longer-term, to hospitalize and later sustain client in protected setting.: 
APPENDIX B 
TABLE XI

AGE RANGE AND SEX OF CLOSED CASES,

BY NUMBER ANND PERCENT

\begin{tabular}{|c|c|c|c|c|c|c|}
\hline \multirow{2}{*}{$\begin{array}{c}\text { Age } \\
\text { Range }\end{array}$} & \multicolumn{2}{|c|}{ Males } & \multicolumn{2}{|c|}{ Females } & \multicolumn{2}{|c|}{ Total } \\
\hline & 非 & $\%$ & 非 & $\%$ & 韭 & $\%$ \\
\hline $\begin{array}{r}0-20 \\
21-30 \\
31-40 \\
41-50 \\
51-60 \\
61-70 \\
71-30 \\
81-90 \\
91-100 \\
\text { TOTALS: }\end{array}$ & $\begin{array}{r}5 \\
1 \\
7 \\
1 \\
4 \\
13 \\
20 \\
11 \\
2 \\
64\end{array}$ & $\begin{array}{r}8 \\
2 \\
11 \\
2 \\
6 \\
20 \\
31 \\
17 \\
3 \\
100\end{array}$ & $\begin{array}{r}3 \\
1 \\
1 \\
2 \\
7 \\
15 \\
24 \\
26 \\
11 \\
90\end{array}$ & $\begin{array}{r}3 \\
1 \\
1 \\
2 \\
8 \\
17 \\
27 \\
29 \\
12 \\
100\end{array}$ & $\begin{array}{r}8 \\
2 \\
8 \\
3 \\
11 \\
28 \\
44 \\
37 \\
13 \\
154\end{array}$ & $\begin{array}{r}5 \\
1 \\
5 \\
2 \\
7 \\
18 \\
29 \\
24 \\
9 \\
100\end{array}$ \\
\hline
\end{tabular}

TABLE XII

YEAR AND TYPE OF APPOINTMENT OF CLOSED CASES, BY NUMBER

\begin{tabular}{|c|c|c|c|}
\hline $\begin{array}{l}\text { Pear of } \\
\text { Appointment }\end{array}$ & Guardianship & Conservatorship & $\begin{array}{c}\text { Joint } \\
\text { Appointment }\end{array}$ \\
\hline $\begin{array}{l}1971 \\
1972 \\
1973 \\
1974 \\
1975 \\
1976 \\
1977\end{array}$ & $\begin{array}{l}- \\
- \\
- \\
4 \\
4 \\
8 \\
8\end{array}$ & $\begin{array}{l}- \\
- \\
- \\
7 \\
9 \\
4 \\
5 \\
\end{array}$ & $\begin{array}{r}17 \\
36 \\
35 \\
3 \\
3 \\
8 \\
3 \\
\end{array}$ \\
\hline Subtotals & s: 24 & 25 & 105 \\
\hline Total: & 154 & & \\
\hline
\end{tabular}


TABLE XIII

INITIAL REFERRAL AND PRIMARY SERVICE-PROVIDING AGENCIES OF CLOSED CASES, BY NUMBER

Referring Agency

\# Service-Providing Agency

\#

$\begin{array}{lrlr}\text { Hospitals } & 32 & \text { Metropolitan Family Service } & 30 \\ \text { Metropolitan Family Service } & 30 & \text { Adult \& Family Services } & 18 \\ \text { Adult \& Family Services } & 24 & \text { Assoc. of Retarded Citizens } & 4 \\ \text { Project ABLE } & 8 & \text { Children's Services Division } & 3 \\ \text { Veteran's Administration } & 4 & \text { Veteran's Administration } & 3 \\ \text { Other Agencies } & 10 & \text { Other Agencies } & 9 \\ \text { Unknown } & \frac{46}{54} & \text { Unknown } & \text { TOTAL }\end{array}$

TABLE XIV

REASONS FOR TERMINATION OF CLOSED CASES, BY NUMBER AND PERCENT

\section{Reason}

Death

Refer to private Guardian/Conservator

Adult and Family Services

Restore to competency

Temporary guardianship only

Unknown

Minor reaching age 18

Conservatorship to Veteran's Administration

Move

Marriage

Legal problems resolved

Dis appeared

Juvinile Court wardship
非 $\%$

$\begin{array}{lrr} & 51 & 33 \\ \text { tor } & 35 & 23 \\ & 28 & 18 \\ & 16 & 10 \\ & 9 & 6 \\ & 4 & 3 \\ \text { istration } & 3 & 2 \\ & 3 & 2 \\ & 1 & 1 \\ & 1 & 1 \\ & 1 & 1 \\ \text { TOTAL } & 1 & 1 \\ & 154 & 102 \\ & 154\end{array}$

FTotal does not equal 100 due to rounding. 